\title{
Managing the Urban Environment of Lima, Peru
}

\author{
David J. Edelman \\ School of Planning, College of Design, Architecture, Art and Planning, University of Cincinnati, Cincinnati, USA \\ Email: david.edelman@uc.edu
}

How to cite this paper: Edelman, D. J. (2018). Managing the Urban Environment of Lima, Peru. Advances in Applied Sociology, 8, 233-284.

https://doi.org/10.4236/aasoci.2018.83014

Received: February 22, 2018

Accepted: March 27, 2018

Published: March 30, 2018

Copyright (C) 2018 by author and Scientific Research Publishing Inc. This work is licensed under the Creative Commons Attribution International License (CC BY 4.0).

http://creativecommons.org/licenses/by/4.0/

\begin{abstract}
This article brings the contemporary thinking and practice of Urban Environmental Management (UEM) to the solution of real problems in a major city of a developing country in Latin America. Such cities both face more immediate problems than the developed world and have fewer resources to deal with them. The study first considers the Latin American context and then reviews issues of poverty alleviation, industry, sewage and sanitation, water, energy, transportation and finance in Lima, Peru. Finally, it proposes a 5-year plan to help solve the urban environmental problems of Metropolitan Lima, an environmentally difficult, but important Latin American metropolitan area located between the Pacific Ocean and a hilly desert, utilizing a real-world database and a limited budget.
\end{abstract}

\section{Keywords}

Urban Environmental Management, Regional Planning, Developing Countries, Metropolitan Lima

\section{Introduction}

This article focuses on the practice of Urban Environmental Management (UEM) in developing countries, which face more immediate problems than the developed world and have fewer resources to deal with them. It summarizes the results of a graduate level workshop that took place at the School of Planning, College of Design, Architecture, Art and Planning, University of Cincinnati, USA from August through December 2017. The objective of the workshop was to prepare students to work overseas in data-poor environments as professional consulting planners. Several lectures were given to set the framework for the class of 15 students to operate in sector-level working groups or teams (poverty alleviation, industry, sewage and sanitation, water, energy, transportation and finance) preparing a 5-year plan to help solve the urban environmental problems 
of Lima, Peru, an environmentally difficult, but important Latin American metropolitan area located between the Pacific Ocean and a hilly desert, utilizing a real-world database and a limited budget. This project formed the majority of class work culminating in the preparation of a professional quality document.

\section{The Latin American Context}

Urban Environmental Management has received substantial attention since 1970 in both developed countries, where it has emerged as a subject of academic research and professional interest, and in developing countries, where it has increasingly become an area of donor concern. As a field, it is more like planning or engineering rather than geography, economics or sociology; and it represents an integrated view of environmental problems at city, and increasingly, regional level. Such problems are multi-sectoral (e.g., manufacturing, services, household, etc.), multisystem (e.g., water supply, sanitation, transport, etc.), multi-level (central, regional, local and community) and multi-actor (e.g., government, $\mathrm{NGO}, \mathrm{CBO}$ and private). They require solutions of enormous complexity, and those professionals who coordinate the planning, implementation and management of the process must be able to communicate with specialists from many disciplines and professions, such as biology, chemistry, engineering, city planning, public administration, social sciences and law (Edelman, Schuster, \& Said, 2017).

Of interest here, however, is the fact that much of the international attention to this growing field has focused, as is the case with most scientific fields, on the English language literature. That is, most of the knowledge on emerging environmental issues occurs in centers of research and technological development of the "North," pointing to a lack of capacity in scientific and technological self-determination to feed sustainable policy development in Latin American countries (Fernández, 2000). Nevertheless, much professional work of interest has been taking place in Latin America, where the problems of the urban environment have been identified early and considered major difficulties in the development of this heavily urbanized region (e.g., Miranda, Calderón, \& Díaz Palacios, 1996; Schuster \& Edelman, 2002; Schuster \& Edelman, 2003). The former President of the Inter-American Development Bank (IDB), Enrique Iglesias, has stressed the importance of cities, democratization, decentralization and infrastructure, among other themes important in the urban sector of Latin America. These points converge in the urban environment. Lima, then, as one of the largest and most important cities in the Western Hemisphere, provides a case study of how to manage the urban environment in Latin America.

\section{Poverty Alleviation}

In 2013, $12.8 \%$ of the population of the Metropolitan Lima was living in poverty (Roman et al., 2007). A household is considered to be in poverty if it is unable to access a basic food basket and other household goods and services, such as 
clothing, housing, education, transportation, health, etc. While the level of poverty has decreased from $2011(15.6 \%)$ and 2012 (14.5\%), it is still high. The area in Lima with the highest level of poverty is Lima Sur (17.7\%), followed by Lima Este (14.5\%), Lima Norte (14.1\%) and Lima Centro (6.2\%). In addition, $0.2 \%$ of the population lives in extreme poverty, meaning that they are unable to access a basic food basket (Ibid.).

In reality, there are two Peru's: an effervescent Lima, eleven million strong, and the more than 20 million who live outside it. While the poverty rate in Lima fell to $12.8 \%$ in 2013 from $44.8 \%$ in 2004, the rural Andes and Amazon languish in nearly feudal conditions. According to the World Bank, a citizen of Lima earns 21 times more than a resident of the outback, where the rural poverty rate is a staggering $54 \%$ (Arana, 2013). To make matters worse, there is a starkly racial problem: the poor are the dark-skinned and indigenous, while the rich, getting richer, are mostly white (Ibid.).

\subsection{Problem Statement}

The United Nations defines absolute poverty as "a condition characterized by severe deprivation of basic human needs, including food, safe drinking water, sanitation facilities, health, shelter, education and information" (UN Habitat, 2005), and the World Bank states, "a person is considered poor if his or her consumption or income level falls below some minimum level necessary to meet basic needs" (World Bank, 2007). That is, poverty is associated with the lack of appropriate infrastructure, an inadequate transportation system, the lack of accessibility to safe drinking water, insufficient sewage and sanitation systems, as well as energy and industry issues, all of which are investigated by each sector team and which will be reviewed in the succeeding sections of this article. In this section, the goals for poverty alleviation and the suggested programs to implement them concentrate on one major issue in Lima-housing for the poor.

\subsection{State of Housing Conditions in Lima}

An Inter-American Development Bank (IDB) study reveals that among 18 Latin America and Caribbean countries, over two-thirds of households in Bolivia, Peru, Nicaragua and Guatemala have sub-standard housing. Despite the unprecedented economic boom, $72 \%$ of families live without adequate housing, and the housing deficit in Peru is ranked third behind Nicaragua and Bolivia (IDB, 2012). Moreover, UN Habitat states that the lack of decent housing has a strong correlation with poverty and economic underdevelopment at the national level (UN Habitat, 2005). Inadequate housing usually appears with little or no access to basic needs, such as clean water, electricity, sewage and waste management, health services and basic education. Although the government has conducted many housing programs, such as providing finance through Fondo Mivivienda, with more disbursement in Lima than in other areas, the city still has a massive unmet demand for formal housing.

Based on the recognition of problems associated with poverty in Lima, and the 
essential needs of poor people in order to improve their quality of life, the poverty alleviation team of this study proposes the following goals:

- A housing program in low-income areas, which

- Includes a water and sewage system, gas and electricity, and

- Fights against gated communities and the segregation of low-income and high-income people, and

- A housing finance program, which

- Allocates funds and loans for low-income people and others who live under the poverty line.

\subsection{Housing for the Urban Poor}

The main problem of the poverty areas in Lima, then, is housing; that is, most of these areas do not have suitable housing. The structures are built of cheap materials, which are not durable. Based on the United Nations goals for poverty alleviation, the first step that needs to be taken is to build durable houses with resistant materials and appropriate infrastructure. Therefore, three proposals for a housing program are suggested in the slum areas of Comas, San Juan and Villa El Salvador. The proposed main partners for cooperation in this project are the Municipality of Lima, the National Housing Ministry, the World Bank, USAID and local NGOs.

\subsubsection{ABOD Units}

The first proposed housing project to be implemented is composed of $\mathrm{ABOD}$ units. ABOD Shelters is a South African Company, which designs constructed units for low-income housing. ABOD Shelters provides a wide range of options for low cost housing and inspires community design in areas that are presently informal settlements or where large numbers of families lack homes of any substance (ABOD, n. d.). Figure 1 illustrates two examples. ABOD Shelters seeks to expand its work, and the company is very eager to establish branches throughout the world. The climate is approximately same in South Africa and Peru; therefore, ABOD Shelters' design is a good option for Lima.

Reasons why this company has been chosen is that it has been very successful with its projects in Africa, the design is suitable for Lima's weather conditions, and the costs are relatively reasonable in comparison to other companies. In order, then, to find out whether ABOD units would be successful in Lima, a one-year pilot project for which $100 \mathrm{ABOD}$ units are to be imported is suggested. If successful, ABOD Shelters could establish a subsidiary in Lima. This would have two benefits for the housing program, should it continue with ABOD units. First, the cost of units would decrease because they would be produced with domestic materials and by local workers. Second, ABOD Shelters would create jobs for the slum dwellers.

\subsubsection{Tiny Homes Project}

The second proposed housing project to be implemented is the Tiny Homes 

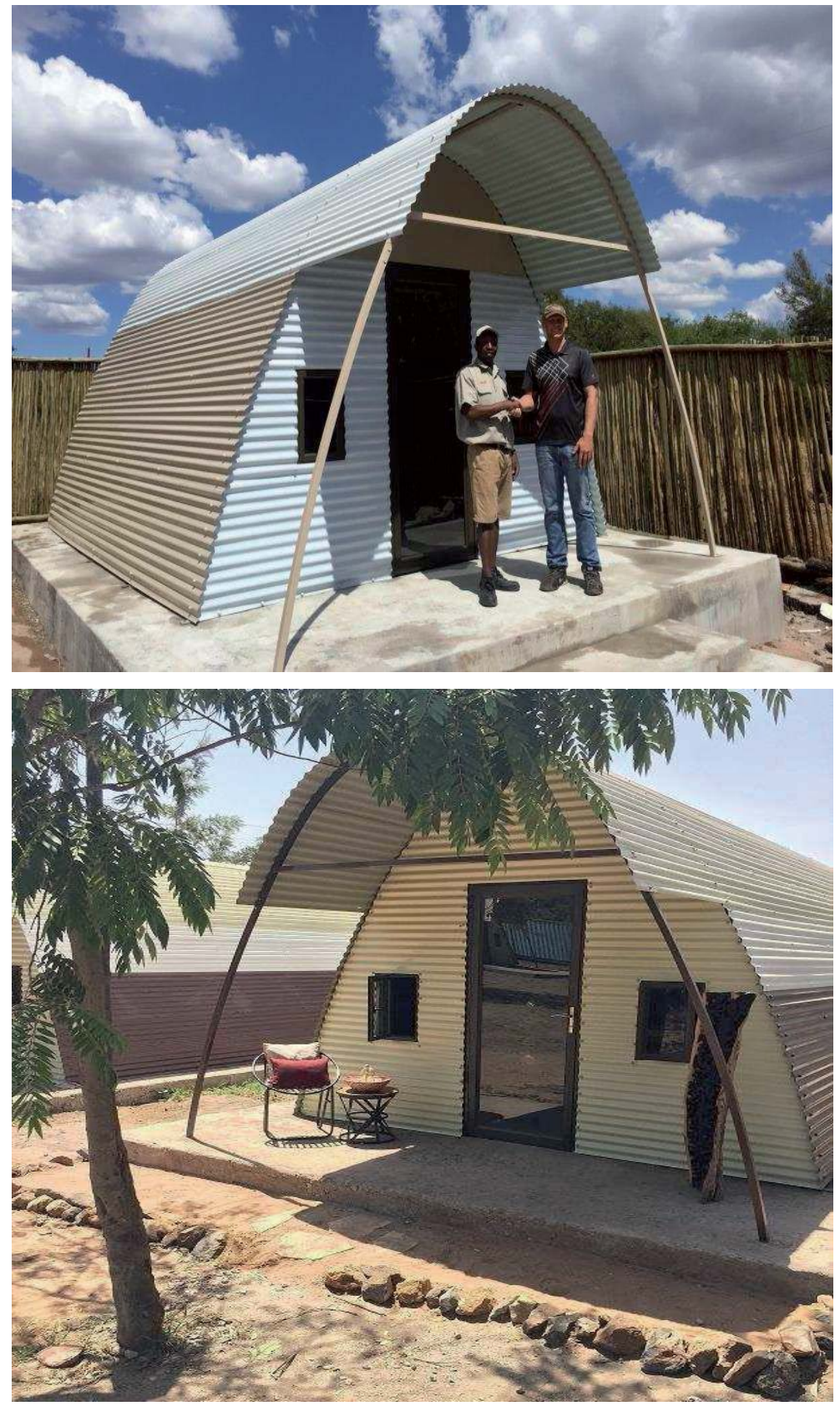

Figure 1. ABOD simple design. Source: ABOD official website, 2017.

project. The objective here is to build cheap Tiny Homes by using domestic workers and local materials for low-income people in the three identified slum areas. This type of project has been completed in a number of different countries. The idea of this project comes from the successful experience of Tiny Homes in Detroit, USA in 2017, where a neighborhood based on these cheap structures was developed for low-income people with a specific plan for the rent and ownership of these houses based on the income of poor residents.

In order to implement this program in Lima, the poverty alleviation team searched for local companies that are already building houses and found a com- 
pany named CAPECO, which is very well known in Peru's housing sector. The Tiny Homes project would be implemented in Lima by CAPECO. This project is not only designed to provide cheap Tiny Homes with durable domestic materials such as cement and bricks, but also to create more jobs for domestic workers. The housing finance program is also suggested in order to enable rent and ownership based on the income of the poor areas of Lima.

Figure 2 shows Tiny Homes in Detroit for the purpose of illustration. The simple architecture of the houses is merely suggestive, as the houses constructed in Lima would be based on local designs.

\subsection{Affordable Housing Finance}

The basic prerequisite for building homes for low-income families is to have a financial mechanism. UN Habitat (2008) states that the only way to finance housing and infrastructure is through a partnership between the government and the private sector. In Peru, the Fondo Mivivenda is the main public institution to provide affordable housing (Fernández-Maldonado \& Bredenoord, 2010).

While Peru's government has numerous progressive housing programs, the housing projects suggested here would be supported by the Ministry of Housing, Construction and Sanitation through a state subsidy program, which would consider the economic situation of the slum dwellers not able to buy even affordable housing. This initiative would be managed and supported by the Fondo Mivivienda. The Fondo Hipotecario de Promoción de la Vivienda-Fondo Mivivienda (FMV) was created in 1999 to solve financial problems and improve access to housing. By law, FMV facilitates access to private housing and promotes mortgage loans with help from private participation (UN Habitat, op. cit.).

Based on Fondo Mivivienda's September 2017 Bulletin, the Fondo Mivivienda has five types of product, of which the most appropriate here is the Financiamiento Complementario Techo Propio or Techo Propio. Mortgage credit related to the Techo Propio program is given by a financial institution to cover the difference between the value of a house to be acquired, built or improved and a family's savings along with the expected subsidy granted by the State. Thus, the final price of an ABOD housing unit through the Techo Propio program for one family or individual whose name is under contract for this grant is quite affordable. The mortgage scheme would have an annual fixed interest rate of $12 \%$ for the 10 years of repayment, and given a $10 \%$ down payment and the expected government subsidy, the monthly payment would be US\$ 34 or S/.110.

In contrast, the final price of a Tiny Homes unit through the Techo Propio program for one family or individual whose name is under contract for this grant is slightly more expensive, but still affordable. The mortgage scheme would have an annual fixed interest rate of $12 \%$ for the 10 years of repayment. Given a $10 \%$ down payment and expected government subsidy, the monthly 

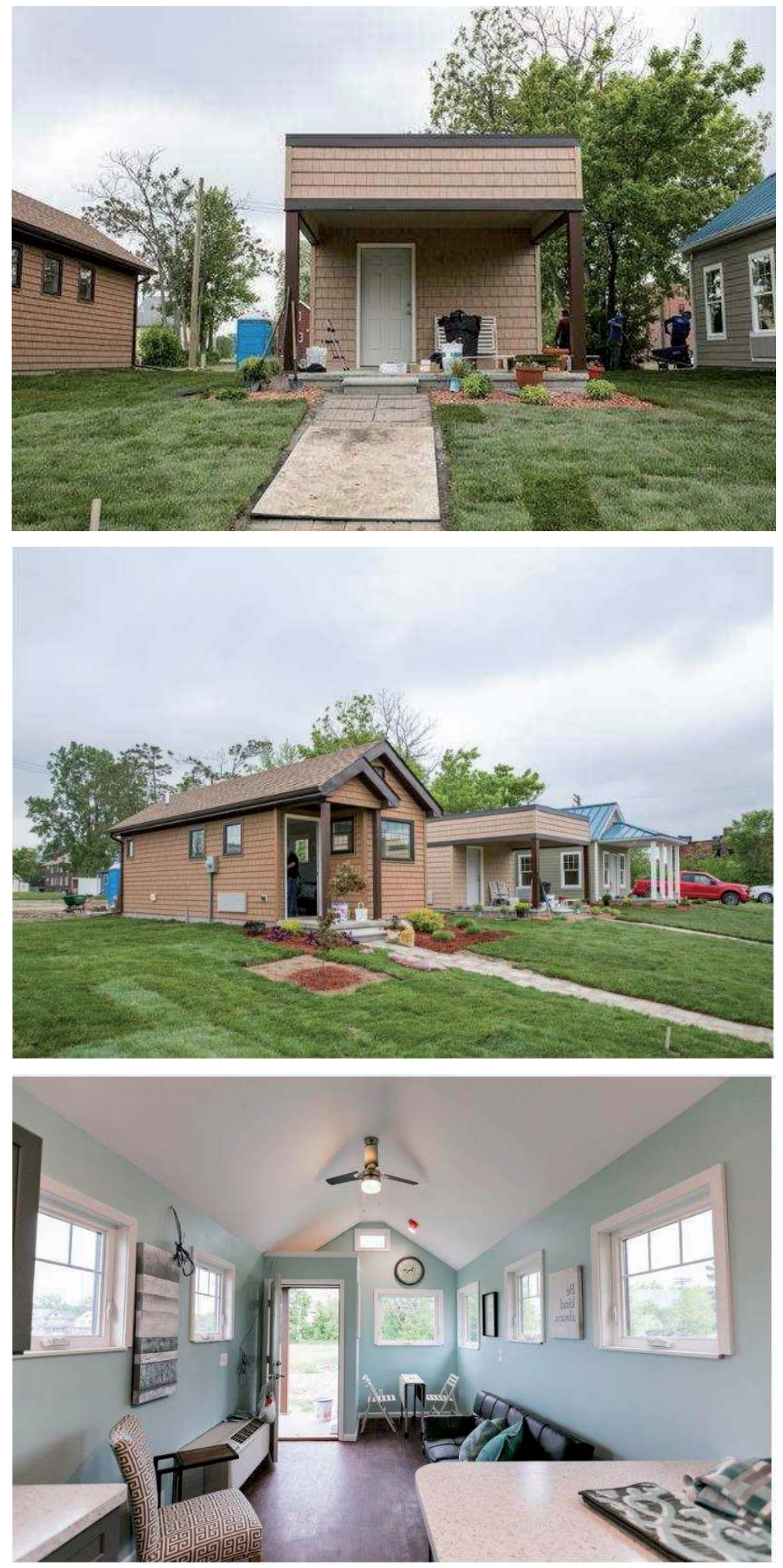

Figure 2. Tiny Homes previous work and indoor preview. Source: Cass Community Social Services website, 2017.

payment would be US $\$ 50$ or $S / .162$. The amount of the government subsidy used in the calculations is based on a case study by ACCION International 


\subsection{Total Cost of Housing Program}

Table 1 summarizes the total costs of the housing program. This includes the construction and funding of $1850 \mathrm{ABOD}$ units and Tiny Homes over the five years of the environmental plan, the mortgage finance for those homes and the construction of a Housing Bank to grant and manage the mortgages.

\section{Industry}

Lima, as the capital and the largest city of Peru, is the leading industrial, financial and retail center of the nation. Lima's impact goes far beyond the economy, strongly influencing the political and cultural life of Peru. With nearly $30 \%$ of the country's population, the city accounts for about $53 \%$ of the nation's gross domestic product (GDP) and generates $35 \%$ of its industrial production (INEI, 2015). The port at Callao, part of the Lima Metropolitan Area, is Peru's main import and export route. Almost all of the country's heavy industries are located in and around Lima, including chemicals, leather, paper, and oil derivatives. Besides these heavy industries, some light industries, such as textiles, clothing and food, are also manufactured and/or processed in Lima (Important Facts and Figures about Lima, the Capital of the Republic of Peru, 2017).

\subsection{Economic Outlook}

After the sharp decline in GDP in 2009, the economy shifted to more solid growth principles. Domestic demand has been the main driver of growth as an overall improvement in confidence in the economy, which in turn has boosted domestic consumption and investment. Moreover, the steady fiscal consolidation that led to a number of budget surpluses in the past decade has increased confidence in public finances and allowed for productive public expenditures. A period of relatively stable inflation and the progressive appreciation of the national currency, the sole, also helped the economy overcome periods of nominal volatility (Peru Economy - GDP, Inflation, CPI and Interest Rate, 2017). While the

Table 1. Estimated total cost of housing development program.

\begin{tabular}{ccc}
\hline Type of Cost & Cost in US\$ & Cost in Soles \\
\hline Upper Value Mortgage Loan & $20,000,000$ & $64,700,000$ \\
(ABOD \& Tiny Home) & & $486,500,000$ \\
Housing Bank Physical Constructions & 150,000 & \\
(3 selected slum areas) & & $48,500,000$ \\
Median Value Housing Construction & 15,000 & $113,200,000$ \\
(ABOD \& Tiny Home) & & \\
Grand Total & $35,200,000$ & \\
\hline
\end{tabular}

Source: Author. 
external sector's contribution to the economy has diminished significantly, exports have remained strong, made possible by Peru's favorable location and trading arrangements. Moreover, the import of capital goods has remained at healthy levels, which indicates considerable productive activity, fewer imported consumer goods, economic growth and higher employment in the coming years (Ibid.).

\subsection{Problem Statement}

Further growth, however, can be achieved only when high-performing sectors of industry are maximized while underperforming areas are minimized. Even more important, however, the entire industrial sector faces the challenges of a faulty economic framework, unfavorable climatic conditions, a less than ideal state of the global economy, and poor local productivity levels, which, if improved, could enhance Lima's future growth.

Taking the sectors one by one, the first is the agricultural sector. The Central Reserve Bank (BCR) of Lima reported that the farming sector's production increased $6.4 \%$ in June 2017, thus reversing the previous 4-month fall. This was an expansion of $10.2 \%$ in the sixth month of the current year. This rise was driven by blueberries, which contributed $2.7 \%$ to the sector's growth, while the livestock yield slid $1.8 \%$. The overall good results have been widely attributed to favorable climatic conditions (Peru: Farming Sector Sees Best Growth in 2 Years, 2017).

As for fishing sector, National Fisheries Society (SNP) President Elena Conterno Martinelli said Peru's fishing industry is expected to grow $40 \%$, underpinned by greater catches of anchovy, in line with Central Reserve Bank estimates. Again, the sector benefited from climate change (Ibid.). Consequently, since more than a quarter of all Peruvians are employed in either agriculture or fishing for their main source of income (Peru's Fishing Industry likely to Expand $40 \%$ this Year, 2017), a large part of the economy is reliant on favorable climatic conditions.

It is no surprise that these climate-related industries experience challenges due to the specific location and climate of Peru, especially Lima, which partly relies on the fishmeal manufacturing industry. Nevertheless, beyond climate, some agricultural regions will face more urgent problems due to inadequate water caused by the EI Niño phenomenon.

In the manufacturing sector, there was a record of $2 \%$ rise in June 2017 . This growth is primarily due to better performance in primary industries, such as increased anchovy catches for indirect human consumption. Refined oil production expanded 20.6\%, whereas non-primary manufacturing fell $3.2 \%$ due to lower yields of consumer and intermediate goods (INEI, op. cit.). This reveals an unbalanced trade of exporting raw materials at low prices, but importing higher-priced finished products, and it keeps the local economy weak in confronting the challenges faced by participating in the global economy.

Most major industries have located within metropolitan Lima because of its 
pool of skilled labor, personal access to government officials, and the benefits of well-established networks of marketing and services. Yet there are still high levels of unemployment, informal economic activities and illegal mining for which the current economic framework has been unable to provide a solution (Robinson, 2016).

Based on these three main sectors in terms of their strengths and potential, the basis for industrial change becomes evident. However, the attempt to transition fully from a raw material-based economy to a finished product exporting country has been hampered by the following:

- A poor infrastructure in electricity and sewage treatment and disposal;

- Inadequate water in agriculture and industrial manufacturing;

- Inadequate skilled manufacturing workers;

- A lack of end-product manufacturing lines in electronics and food;

- A lack of modern technology and techniques, and

- Central political structures affecting private investments.

\subsection{Priorities}

In order to build on what works and confront its challenges, Lima should develop or promote the following projects in this priority order:

- Sustainable Agriculture,

- A Plastic Recycling Plant,

- A Food Processing Company,

- Educational Programs (technical/vocational schools),

- An Electric Bus Assembly Plant and

- Electronics Manufacturing.

\subsection{Proposed Projects}

\subsubsection{Sustainable Agriculture}

Strategic Initiative: Develop drip irrigation infrastructure that leads from the Rímac River basin to agricultural fields within a stipulated mile radius.

Plan: As a result of Lima's inadequate water resources, farmers must find alternatives in irrigation. The UN Food and Agriculture Organization (FAO) is hoping to finance this project in coordination with the industrial sector and cooperation of the sewage and sanitation sector (The Many Benefits of Drip Irrigation, 2017). Fields would be supplied with grey water from the sewage sector, while the industrial sector would provide the drip irrigation tools and equipment, as well as the training, to ensure maximum crop yields. One year is devoted to study and design, and the remaining 4 -year period for implementation.

Capital Cost: The US\$ 4.2 million to be used for building drip irrigation infrastructure would be loans provided by local commercial banks, but guaranteed by FAO. As for the total cost of this project, US\$ 160,000 and S/.129,827 (amounting to a total of US\$200,000) would be used for one year of study and design, while the rest, US\$ 4 million, would be used for construction. 


\subsubsection{Plastic Recycling Plant}

Strategic Initiative: Build a plastic recycling plant in the Lima metropolitan area as a public investment by the government.

Plan: Quite similar to many developing countries, Lima faces the urgent problems of a degraded environment and natural resource depletion. Plastic is the largest solid waste material, which currently is disposed of indiscriminately. Building a plastic recycling plant would reduce pollution and contamination, create a healthier environment, and conserve the use of natural resources by recycling. The process would take one year of study, one year of construction and three years of implementation. This plant would be sited far away from residential and commercial districts because of the inevitable air pollution in transporting garbage, etc., and it would comply with best practices to reduce environmental impacts.

Capital Cost: Based on current plastic recycling and solid waste management plants, it would cost about US\$ 10 million to build a plastic recycling plant to meet the average needs of Metropolitan Lima. The breakdown is as follows: US $\$ 80,000$ together with $\$ / .64,800$ (totaling US\$100,000 for research) would be spent for a one-year study, and US\$ 9.9 million would be used to cover construction; the facility is expected to provide funds for its own maintenance as soon as operation starts.

\subsubsection{Food Processing Company}

Strategic Initiative: The North American company Kraft Heinz would establish a food processing company as a direct foreign investment.

Plan: To accomplish this initiative, a 5-year process would contain one year for study, another year for construction, and the remaining three years for implementation.

Capital Cost: The capital cost for establishing a food processing company would be US\$ 115 million, all provided as an investment by Kraft Heinz. This would include US\$ 800,000 , along with $\$ / .648,000$, for a total cost of US $\$ 1,000,000$ for studies, and US\$ 114 million for the cost of construction.

\subsubsection{Education Program}

Strategic Initiative: Build technical and vocational schools to expand educational opportunities.

Plan: Foreign businesses would build technical and vocational schools to offer educational programs as their corporate social responsibility. This is mutually beneficial, as the schools would produce more skilled personnel for the labor market, while the companies would have ready access to skilled, cheap labor. Through on boarding and on-the-job training, the participating companies would have the opportunity to build their own core teams for newly built plants or subsidiaries. In order to accomplish this, the plan covers a one-year pilot program and four years of implementation.

Capital Cost: The estimated cost of the project is about US\$ 2.5 million, with 
one third provided by each of three foreign investors. These would be Kraft Heinz of the US (food processing project), BYD Auto of China (electric bus assembly project) and Hewlett Packard (HP) of the US (electronics manufacture). In detail, the cost covers US\$400,000 plus S/.324,000 for studies and US\$ 2 million for infrastructure provision

\subsubsection{Electric Bus Assembly Plant}

Strategic Initiative: Establish an electric bus assembly plant by BYD Auto Co., Ltd. as a direct foreign investment.

Plan: The initial stage of the plan would be to establish an electric bus assembly plant in Lima's central industrial area, near the glass factory and offices because of local economies of scale. The project would involve a 6-month study, one year of construction, a 6-month soft opening and 3 years of implementation. It is expected that this electric bus assembly plant would not just serve Lima's population and ease the city's existing transportation problems, but would provide vehicles to the entire Peruvian transportation system and those all across the Latin American region.

Capital Cost: Based on previous investments BYD has made for electric bus assembly plants in similar locations, it would cost about US\$ 450 million. This would include US $\$ 400,000$, together with S/.324,000, for research and US\$ 447.5 million for construction.

\subsubsection{Electronics Manufacturing}

Strategic Initiative: Establish an electronics manufacturing company by US electronics giant, Hewlett Packard (HP) Inc. as a direct foreign investment.

Plan: The plan is for HP to establish an electronics manufacturing plant in the Lima metropolitan area. It would take 6 months of study, 1.5 years of construction, 6 months for a soft opening and 2.5 years for implementation.

Capital Cost: Based on existing HP electronics manufacturing plants, the project would cost about USD\$250 million. This would include US\$2,000,000 and S/.1,620,000 for research and US\$247.5 million for construction.

\subsection{Operation and Maintenance ( 0 \& M) Cost Recovery Plan}

Since these six proposed projects are all directed to building plants to meet urgent local needs, increasing the employment rate, and spurring the national economy, the $\mathrm{O} \& \mathrm{M}$ costs would only come into effect during implementation, when they would be covered by income from plant production instead of by extra investments or charges. Moreover, based on previous case studies and the scale of each proposed project, the $\mathrm{O} \& \mathrm{M}$ fee for the electric bus assembly plant and electronics manufacturing plant would be US\$ 2.5 million for each from income per year. The operation and maintenance costs for food processing would be about US\$ 1.5 million from income per year, and US\$100,000 from income per year would be the $\mathrm{O} \& \mathrm{M}$ cost for the plastic recycling plant. As for the education programs, there would be a US $\$ 300,000 \mathrm{O} \& \mathrm{M}$ fee assessed on the three 
foreign investors per year to ensure smooth implementation. For the drip irrigation infrastructure, the $\mathrm{O} \& \mathrm{M}$ costs are expected to be borne by the farmers using the technology.

\section{Sewage and Sanitation}

\subsection{Background}

Lima straddles two worlds. One of modern technology, fast paced stock trading, international tourism and luxury shopping; and one on the periphery, both physically and figuratively-picking up the trash, supplying the food, working in the factories, struggling to get by on the hope of a better future and the support of family and friends. This Dickensian dichotomy is an aspect of nearly every major city around the world. In this, Lima is not alone. Yet Lima is in a unique position to incorporate the periphery into the formalized socio-economic structure of the city in a way that can transform the lives of every one of its residents.

Over the past decade, Lima has experienced a renaissance in terms of city services that has been led as much by the city and national governments as by the social sector. With new laws and environmental regulations, there has been a transformation from $60 \%$ solid waste collection in 2000 to $88 \%$ in 2014; from $10 \%$ wastewater treatment only two decades ago to nearly $100 \%$ today (Organismo de Evaluación y Fiscalización Ambiental [OEFA], 2014; Food and Agricultural Organization of the United Nations [FAO], 2015). Yet now the challenge is what to do with all that is being collected, in terms of both solid waste and wastewater. The sewage and sanitation team encourage Lima to consider these waste streams as resources.

Just as every other city, Lima should set the ultimate goal of reducing waste. Part of waste reduction is changing consumer habits. However, most waste reduction does not depend on changing use habits alone (Pacala \& Socolow, 2004). Waste can be reduced through the design of circular systems that put the end product, waste, back into the use cycle in one form or another (McDonough \& Braungart, 2002). In the case of Lima, this section looks at both solid household waste streams and treated sewage wastewater in order to design a system to reduce the reliance on natural resources, to lower prices of service delivery and to solve two of the most pressing environmental issues facing Lima-overflowing landfills and water shortages.

\subsection{Current Conditions in Lima-Solid Waste}

The landfill capacity of Lima is inadequate for the amount of solid waste generated by households in the city. The city relies on eight landfills, all of which are near or exceeding capacity (Chauvin, 2009). As a result of the limited landfill capacity, which in turn leads to high disposal costs of over US\$ 32 per ton, much of Lima's waste that is collected is not disposed of properly (Municipalidad Metropolitana de Lima, 2013). Even though the waste may be picked up from houses, it often ends up in rivers, the ocean or illegal and unsanitary dumping 
sites. Of the 8202 tons of household waste generated by Lima on a daily basis, only $20 \%$ is disposed of properly. In other words, 1640 tons of waste end up in landfills on a daily basis, leaving some 6562 tons to find their way into the ocean, the soil or the air through incineration in an unsanitary and unsustainable fashion (Poon, 2016). With the rising cost of land and the "not in my backyard" aversion to the creation of new landfills, simply adding more locations in which to put solid waste is not the most viable option (Livezey, 1980).

\subsection{Priorities-Solid Waste}

The sewage and sanitation team's top priority for Lima's solid waste is to reduce drastically what is destined for landfills or other more environmentally destructive forms of disposal. By doing so, the team believes that the existing landfills would be able to accommodate the lighter load and that the practice of dumping waste into rivers, the ocean and other unregulated dumpsites would cease. If Lima does not adopt an aggressive strategy to reduce, reuse and recycle, it would have to increase its landfill capacity by a factor of roughly five-from eight to 45-in order to accommodate the existing solid waste as well as the projected growth over the next two decades. It is logistically impractical and economically unlikely that such an expansion of landfill capacity could be achieved. In addition, merely storing waste is not ultimately solving the problem. While energy can be captured from landfills, as will be discussed in a later section, a policy solely reliant on waste storage in landfills is simply pushing the problem of waste into the future. Such an approach seems antithetical to the idea that sustainability is to "permit the social, economic and other requirements of present and future generations" (National Environmental Policy Act, 1969). Sustainable waste management must consider both present and future challenges. Reducing, reusing and recycling is therefore urgently necessary as an integral part of a sustainable plan to manage Lima's solid waste.

To achieve the goal of reducing Lima's waste by an amount approaching 77\%, the sewage and sanitation team takes the long view in terms of changing behavior and adding a financial value to waste in order to encourage its reuse as opposed to its harmful dumping. To reuse or recycle what is currently considered waste, the waste stream must first be segregated by type: plastic, metal, compostable organic matter, cardboard and paper are among the principal categories of waste that the team views as a resource. This waste stream segregation is a key element of its plan.

\subsection{Proposed Projects for Solid Waste}

To sort, collect and manage Lima's solid waste, the expansion of an existing organization that is working to do exactly that is proposed. Ciudad Saludable (Healthy City) was founded in 2002 by Albina Ruiz in order to change the way people view waste. Albina Ruiz describes arriving in Lima for the first time from her home in the countryside and being overwhelmed by the amount of garbage, 
a concept that was foreign to her. In her life outside of the city, Albina Ruiz had innately considered waste a resource and made use of nearly everything (Ciudad Saludable, 2011). Her work today through the organization she founded is to bring that mindset to cities across Latin America.

Ciudad Saludable has two side-by-side programs. First, the organization runs educational programs and outreach to schools in order to engage students and their families in efforts to reduce and sort waste. Second, Ciudad Saludable helps organize recyclers into formal worker cooperatives. Ciudad Saludable helps coordinate between these cooperatives and facilitates the construction and maintenance of packing and scrapping facilities for plastic and metal to begin the recycling process.

Ciudad Saludable is taking action on both sides of the equation, working as much to transform household behavior, as it is to strengthen service delivery and recycling worker empowerment through institutional infrastructure. This places the organization in a prime position to lead an expanded effort to engage more households in sorting and to empower more recyclers through organizing and formalization. Since its founding, Ciudad Saludable has worked in 14 of Lima's 43 districts. The sewage and sanitation team seeks to direct funds and support for Ciudad Saludable to expand to all of Lima's districts over the next five years. With the expansion of Ciudad Saludable, the Ministerio del Ambiente MINAM (Ministry of the Environment)'s goal of $100 \%$ collection and disposal by 2021 is closer within reach. By working closely with each community, the team believes the Ciudad Saludable can pave the way for transformative behavior change that truly creates a healthy city far beyond the year 2021 and ultimately accomplishes the waste management objectives of the Peruvian government.

Such an expansion, or tripling the scale of Ciudad Saludable's operations, would come in three phases. The first two phases of 12 to 24 months each would focus on a different set of 14 to 15 of Lima's municipal districts. Ciudad Saludable would bring its education program on waste stream segregation into every primary school within those districts. The strategy is to reach households by reaching children and pushing information upstream to their parents. Students are a captive audience, and Ciudad Saludable would work with schools to develop habits of separating the waste generated on each campus. Ciudad Saludable would provide schools with adequate containers for such separation of waste just as the organization has already done in 14 districts with the help of foreign donors such as USAID and the Skoll Foundation.

In tandem with the school-based education programs, Ciudad Saludable would help organize cooperatives of people collecting and recycling waste. These cooperatives would scale up into the formal sector first by collecting the newly sorted waste at each school across the district where Ciudad Saludable has run its education program and provided waste containers. Collector and recycler cooperatives have a strong history of success across Latin America and in Peru 
specifically.

Across Latin America and around the world, recycling collectors are organizing to turn trash into cash (El Espectador, 2017). There are over 108,000 recycling collectors in Peru, who since the passage of a law in 2009 have been organizing into formal cooperatives (Ciudad Saludable, 2015). In the 14 districts of Lima where Ciudad Saludable has already undertaken its work, more than 1500 people have joined cooperatives as worker-owners of small-scale waste management enterprises that bridge the gap between the public and private sector. The cooperatives derive their income through fees charged for collection and through the sale of the products that can be recycled and reused. This market mechanism links the sorting of materials to a value chain where what was previously thought of as waste can now have financial worth.

The third and final phase in terms of Ciudad Saludable's work to scale up waste sorting builds on the awareness raised through the in-school education program to conduct a public awareness campaign across the entire City of Lima. Utilizing social media, online advertising, along with television, print and billboard advertising, the idea of waste separation would confront every resident of Lima. While students and their families would have been targeted through school-based programming in the first two district specific phases, the final phase aims to connect with every resident of the city in preparation for any waste container distribution that may occur outside the scope of this project.

\subsection{Capital Costs for the Solid Waste Sector}

Ciudad Saludable has managed to work in 14 of Lima's districts with a budget of US\$ 1.2 million per year (Graf \& Kayser, 2014). It is proposed to add an additional US\$ 3.6 million dollars to the organization's existing yearly budget over the course of the 3 to 5 -year project. Funding would be obtained from existing partners and is detailed in the section on finance. Such a budgetary expansion facilitates the hiring of the personnel necessary to run workshop style education programs across all of Lima's primary schools and to coordinate with the city's waste collectors and recyclers. Considering that there is significant overlap with the existing operations of the organization in terms of baseline overhead, it is projected that with these increased resources Ciudad Saludable would have the necessary funding to run a strategic, citywide awareness campaign in the final year of the program and to facilitate the design of a number of waste collection containers. Such containers would only be prototyped. The manufacturing and distribution of the varying types of waste containers should be prescribed through their design and then conducted as a separate project outside of the scope of this proposal. The design process would be a collaborative effort between city residents, collection and recycling cooperatives and universities throughout Lima. As a not-for-profit organization with a track record of success, Ciudad Saludable is well positioned to oversee the successful management of these funds and make efficient use of them. 
In summary, the entire 3 to 5 -year project would cost between US\$ 7.2 and US\$ 9.6 million with US\$ 3.6 to US\$ 6 million coming from Ciudad Saludable's existing funding sources and ongoing operating budget and US\$ 3.6 million provided as additional funding over the course of the program. While there are other costs to consider outside of this program, such as the cost of waste containers, the total budget for this approach to waste management is significantly less than the construction of a large-scale waste sorting facility and is undoubtedly less than the costs associated with adding nearly 40 landfills to Lima's infrastructure.

\subsection{Current Conditions in Lima-Sewage}

Lima's largest challenge in terms of sewage is water. Scarcity of water has long been a major issue in Lima, a city in a desert. Recently, it has given rise to a number of political slogans and more importantly a number of major public works. Much as Lima is moving in the direction of total waste collection, it is also moving in the direction of total water and sewage service (The World Bank, 1991). The principle public utility behind water and sewage is the Servicio de Agua Potabley Alcantarillado de Lima or SEDAPAL. The organization, which is government owned but operates semi-autonomously, is in the middle of a multi-billion dollar infrastructure buildout, including two wastewater treatment plants. One of these plants, PTAR Taboada, is the largest in South America, serving over 4.7 million people with a capacity of $14 \mathrm{~m}^{3} / \mathrm{s}$, or $72 \%$ of the wastewater generated by the City of Lima (Tedagua, 2014). The grey water leaving Lima's wastewater treatment plants is currently pumped into the ocean.

With funding arranged through various sources, including the World Bank and the Peruvian government, SEDAPAL has a plan to lay all of the pipes to connect homes and offices throughout the city to water and sewage service by 2020 (Barrett, 2017). As this project continues to take shape, the sewage and sanitation team's concern is less with connecting sewage services to households than it is with what to do with the fact that Lima may run out of water as soon as 2030 (Lineback \& Gritzner, 2010). Currently, the majority of Lima's water comes from the three river valleys that are fed by melting glaciers in the Andean mountain range. Before that water gets to the city, $70 \%$ of it is used by the farms that line the river valleys along three rivers-the Chillón, the Rímac and the Lorín (Export.gov, 2017). This fact alone drives up the cost of water for the City of Lima, where the average family pays US\$ 25 per month for water (Mervin, 2015). Couple the competition over water with the fact that the glaciers feeding the rivers are receding, Lima is headed for disaster. Without the glaciers, there will be no source of water-neither for agriculture nor for residential uses. Without water, there is no sewage system. Without water, there is no city.

\subsection{Priorities-Sewage}

While the focus of this section is sewage and not water, it is important to make 
clear that sewage and water are co-dependent. The sewage system must have water to flush waste through the pipes or else the backup will become unsanitary. Likewise, a water system must have a sewer system to capture wastewater. If either of these systems break down, both will fail.

The sewage and sanitation team's priorities are to alleviate the water scarcity for urban uses immediately, and, in the long term, to ensure a source of water for the vital agricultural production on the periphery of Lima. To accomplish both of these goals, Lima must view its treated wastewater as a resource.

Much of the work to capture this resource has already been done. In the last ten years, SEDAPAL has invested at least US\$ 300 million into sewage treatment plants. These wastewater treatment plants are up and running. Whereas 20 years ago Lima dumped nearly $90 \%$ of its raw sewage into the ocean, today, it is dumping all of its treated sewage into the ocean. While it is better that the sewage be treated, the ocean does not need more water for the foreseeable future. On the other hand, Lima's water supply is urgently running out. It is proposed here to redirect the treated wastewater from the ocean into agricultural fields.

\subsection{Proposed Projects for the Sewage Sector}

Lima's agriculture is situated primarily in the three river valleys that currently supply Lima's water. Each of those river valleys would be connected to a wastewater treatment plant. The construction of the three pipelines would be carried out over three 18-month phases during the entire 5-year project period, followed by a 6 -month review period. Each phase would begin with a site plan evaluation period in order to map a path for the pipelines. It is expected that the site plan evaluation for each pipeline would last around six months and for the construction to last around one year for each pipeline.

The water delivered through the pipelines would service approximately 5000 hectares of farmland and roughly the same number of farmers. The scale of construction for these projects is disproportionally large if those farmers are considered as the only beneficiaries of the pipeline; but the farmers use a disproportionately large amount of water. Roughly $70 \%$ of the water supply for Lima is used in its agricultural periphery (Export.gov, op. cit.). Farmers are also not the only beneficiaries of the project. Lima's agricultural sector, cradled within the converging river valleys, gave rise to the city and continues to supply the city with food and contribute to the nation's GDP (FAO, 2015). The pipelines would ensure that Lima's agriculture has water for generations to come. This means that the pipelines go a long way to ensuring Lima has food for future generations. In addition, the pipelines would immediately reduce the demand for fresh water and increase the overall water supply in the region. This should lower the cost of water for Lima in general. Whether individual households experience lower water costs right away is up to decision makers within SEDAPAL and other government officials, who could decide to take the money saved through lower water supply costs and invest it in desalination plants. Either way, even- 
tually the savings would be passed onto Lima's residents. In other words, these pipelines are not just for Lima's farmers, but they help ensure that Lima has a future with affordable water and food.

\subsection{Capital Costs for the Sewage Sector}

The sewage and sanitation team projects the entire cost of constructing three pipelines over five years to be US\$ 35 million. This cost excludes the irrigation systems and education programs covered by other sectors. This projection is based on the cost of US\$300,000 per kilometer of pipeline, which is the figure that the World Bank (2014) has used to calculate its loans to SEDAPAL. In addition, it is estimated that the construction of pumping facilities would cost $\$ 350,000$ for every $10 \mathrm{~km}$ of pipeline. This cost is derived by comparison to similar pipeline projects (Miriam Vale Shire Council, 2007; Skinner, 2017). On top of construction costs, US $\$ 500,000$ has been allocated for each phase of site evaluation. The team has also planned for an additional US\$ 500,000 to be spent on reviewing the project. If necessary, this fund could be used to pay for unforeseen costs.

The budget for this project would be derived entirely from SEDAPAL's ongoing US\$250 million yearly capital improvement fund that operates until the year 2020. SEDAPAL receives its funding from a variety of sources including the World Bank, other foreign entities and the Peruvian government as is detailed in the financial section of this article.

\section{Water}

\subsection{Background}

Water has historically marked Peru with great protest and strife. During Peru's economic collapse in the 1990s, then president, Alberto Fujimori tried new market policies to mitigate the crisis. One of his many new policies was a plan to privatize the water operations in Lima. Attempts at privatizing water and sanitation largely failed because of water scarcity. According to the World Bank:

[T]he scarcity of water sources meant high marginal costs, partly for pumping water from deep wells and building adequate storage for dry periods. High extraction costs were compounded by years of neglect; much of the system needed to be replaced. Attracting private investors meant setting prices high enough to recover these high costs and provide a reasonable return on capital (Alcazar, $\mathrm{Xu}$ and Zuluaga, 2000).

Lima residents have protested privatized water, and now there is an entirely different water agenda. Peru's current president, Pedro Pablo Kuczynski, inaugurated in 2016, prioritizes water issues. Kuczynski actually ran his campaign with the slogan: "Water for All." The Water for All campaign aims to extend and improve water and sanitation services in the pueblos jovenes (slums). He not only prioritizes water; he is passionate about water. In 2007, he founded a non-governmental organization (NGO) called Agua Limpia, which installs pota- 
ble water systems in vulnerable communities throughout Peru (Collyns, 2015). Kuczynski, "has pledged to eliminate all bureaucratic obstacles to US\$25 billion in delayed infrastructure investment, including 170 large-scale potable water and sewerage projects. He has also announced plans to install connections for water services for $100 \%$ of the population by 2023" (Emery, 2017).

Peruvians' access to water has improved impressively in recent years. In 1990, $74 \%$ of Peruvians had water access, and, in 2015, that increased to $87 \%$ (Kalra et al., 2015). Although these water access improvements are celebratory, with the pace of population growth and decreasing water resources, Lima must account for the following identified problems to operate sustainably its water programs.

\subsection{Problem Statement}

Lima's natural environment is rather paradoxical. "Peru has the largest tropical glaciers in the world," found in the Andes Mountains just beyond Lima (Painter, 2007); yet Lima is the second largest desert city in the world after Cairo, Egypt (Bonzanigo, op. cit.). With an average annual rainfall of just six mm, and most of its water coming from melting glaciers, Lima is in a water crisis. Thankfully, as previously discussed, water is a political priority. Although there has been much improvement in Lima's water situation, long-term water planning is an urgent matter. The water team has identified two main problems: access to water and lack of water.

\subsubsection{Water Access}

Despite SEDAPAL's hefty investment in connecting Metropolitan Lima to its sewer and water lines, there is an ever growing population with which it cannot keep up. This population is mostly domestic, poor economic migrants from the countryside. These migrants often settle on the outskirts of Lima in slums. If a family squats on a parcel long enough, it can own it; if a group of families invest in building houses on their property, the city will eventually absorb the neighborhood and provide services to it.

Thus, Metropolitan Lima continues to grow, and the impoverished hilltops surrounding Lima lack access to running water, among other basic services. The average household uses 240 liters a day; with a price of US\$ 4 for ten cubic liters, these residents pay roughly US\$110 a week for water because, as Figure 3 shows, it must be transported by truck up steep inclines over unpaved roads (Conrad, 2012). There is an estimated $87 \%$ of the population that are connected to Lima's water supply network, leaving roughly $13 \%$ of the population without access (World Bank op. cit.). The neighborhoods most impacted by this water shortage are the impoverished ones.

Moreover, fresh water is simply scarce. Lima sits in a desert, and as the population increases, the limited water sources are depleting quickly. "[T] wo-thirds of the glaciers feeding the Rímac's headwaters have disappeared, decreasing the river's glacier contributed volume by $90 \%$ in the past 40 years" (Kalra et al., op. cit.). Soon, Lima's shrinking glaciers, which melt into rivers, will no longer 


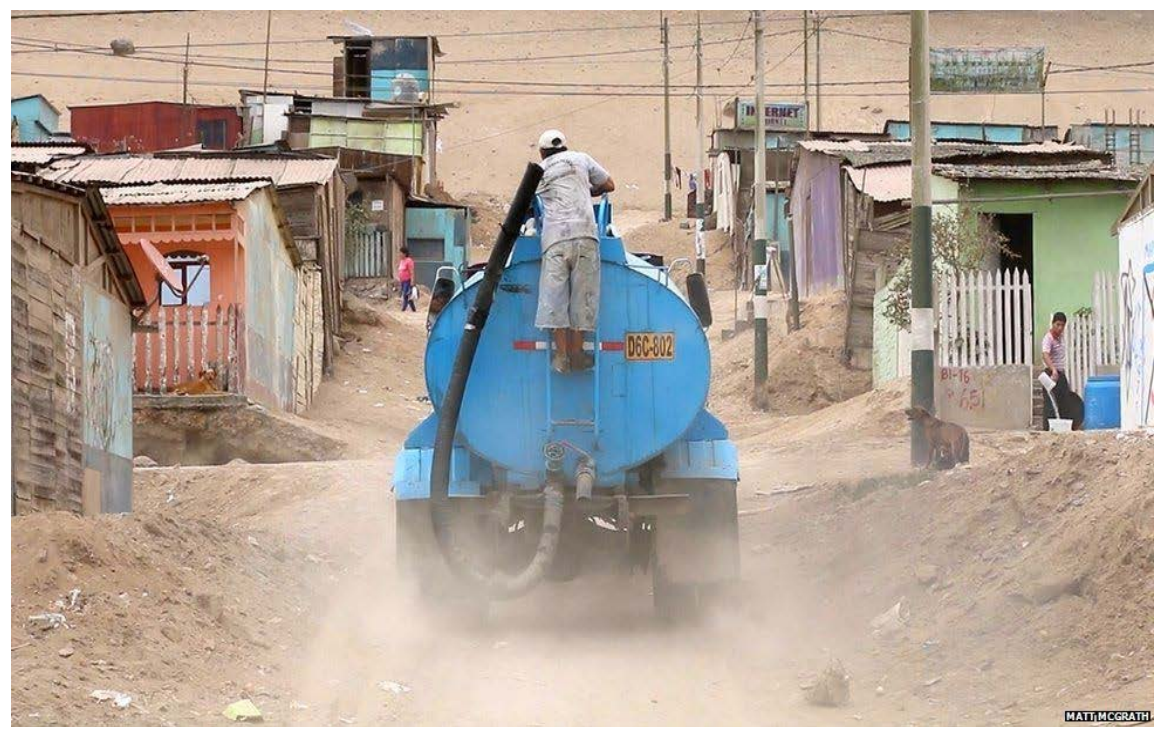

Figure 3. Water delivery on the outskirts of Lima. Source: McGrath, BBC, 2014.

feed into the main water source (the rivers, and especially the Rímac) of Peru's largest city. To secure sustainability, Lima must creatively consider its current water policy.

\subsubsection{Water Usage}

It is critical while operating in a desert that every drop of water is used in the most efficient manner possible. "Just a fifth of Lima's wastewater is treated. The rest-eight of ten gallons-is flushed into the rivers and the Pacific" (Schneider, 2014). Although water treatment plants are on the rise in Lima, grey water could be widely used instead of being discarded. Grey water is water that is reusable from the kitchen sink or shower, and could be used for agriculture or domestic purposes-but not for drinking.

Eighty percent of Peru's water use is from agriculture. If grey water were better distributed to farms, water would be utilized more efficiently. Furthermore, farmers often waste thousands of liters of water by using spray methods as opposed to drip irrigation. Safe grey water uses, affordable drip irrigation practices and water conservation practices are not common knowledge in Lima. This lack of information limits Lima residents' ability to use most effectively the small amount of water they have. Governments often have great ideas; however, often these new practices are not communicated to the public, and then the population does not adopt up-to-date practices.

\subsection{Priorities}

After identifying the principal roots of water problems in Lima, water access and usage, the water team determined the following priorities, which must be addressed. The team did not determine any one of these water aspects to have precedence over another because they are inherently all connected. For instance, Lima could not have a new watering system for farmers without the farmers 
knowing how to use it, or hooking up more families to pipelines if the water source is destroyed. Luckily, the team was able to acknowledge each of these priorities through the projects described below. This complete approach marries well with Lima's comprehensive water plan, which takes into account all of these issues as a priority.

\subsection{Proposed Projects and Justification}

\subsubsection{Community Education Outreach}

To mitigate inefficient water use by farmers and families in Lima, the water team proposes implementing a community outreach water education program. This program has two parts; first, it would target small farmers on the fringe of Metropolitan Lima, and, second, it would target 10 and 11 year old school children. For both parts, representatives of Water for People, a nonprofit, which provides water services and infrastructure installation globally, including in Peru, would train teachers and community leaders to spread the gospel of best practices for water.

\subsubsection{Water Wheel}

Transporting water by truck up mountainsides is a logistical nightmare. The revolving issues regarding this method are chronic shortages, long delivery times, and difficulty in finding a feasible cost point for providing water to these communities. Figure 4 shows that water is not delivered directly to many residences as well. To address this water access issue, the water team proposes the use of Water Wheel technology to assist with the water crisis epidemic for the poor transitional neighborhoods. The Water Wheel is essentially a round 50-liter container that enables individuals to roll water from water sources to their

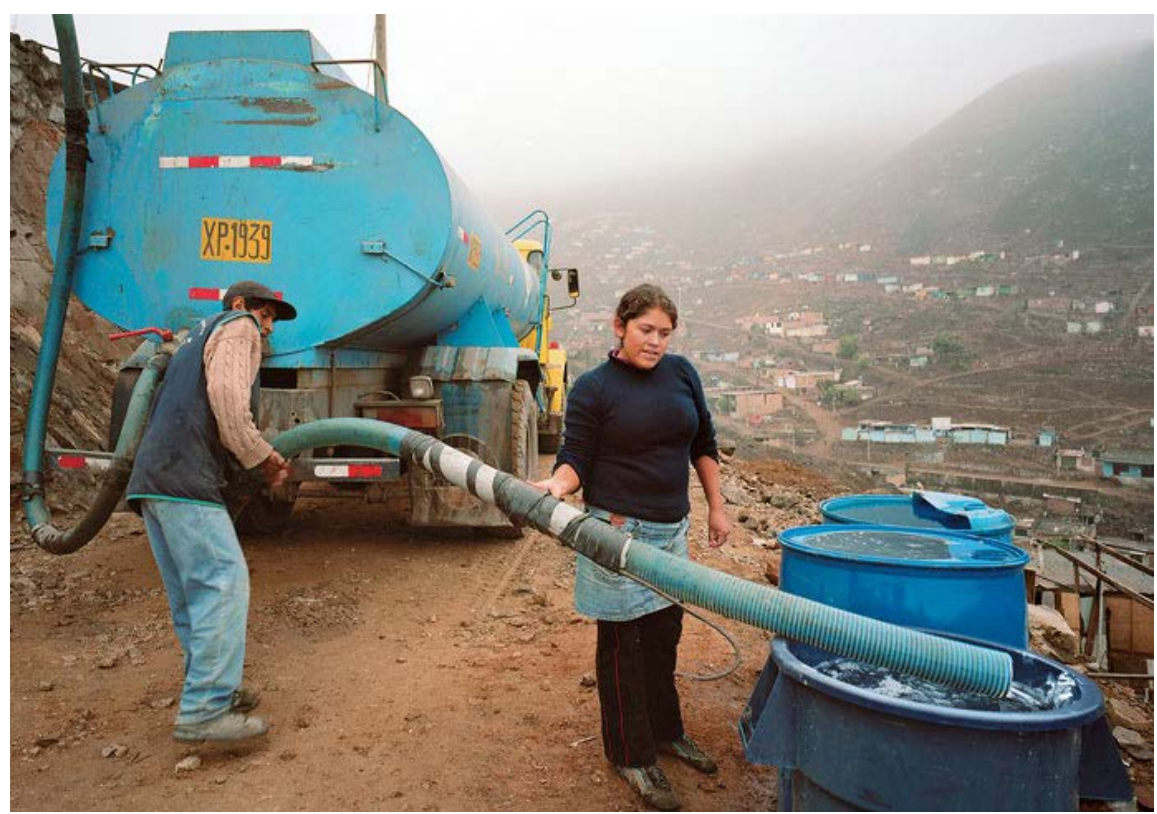

Figure 4. Final delivery point for water on Lima’s outskirts. Source: Black, 2010. 
homes without breaking their backs. Specifically, Water Wheel technology allows the user to transport, store and filter water to ease the burden of water scarcity.

This idea was first tested successfully in northern India (see Figure 5) by an NGO known as Wello. Wello was given US\$100,000 to finance the development and distribution of their technology by a Canadian NGO known as Grand Challenges Canada (Jewell, 2014). Assuming that Grand Challenges is willing to finance this successful project in another setting, the water team believes Grand Challenges Canada would finance a Water Wheel project in Lima. In addition, this organization was also chosen because of its history of funding similar projects to support low- and middle-income countries via technology and business innovation (About Grand Challenges Canada, 2017). Regarding the Water Wheel, it found that women in the tested region spent, on average, $25 \%$ of their day collecting water for their families (Lavars, 2014). From this research, Wello constructed its Water Wheel with the capacity to transport three to five times the amount of water that women in the region were carrying by traditional methods. Wello set its goal to distribute in small amounts Water Wheels to 10,000 to 20,000 customers per year in India (Jewell, op. cit.).

In the context of Lima, the water team proposes to replicate, manufacture and sell Water Wheel technology locally on a large scale. An estimated 50 to 100 new jobs would be created from installing a manufacturing site. Having local production keeps all profits in the most needy neighborhoods. Working with the

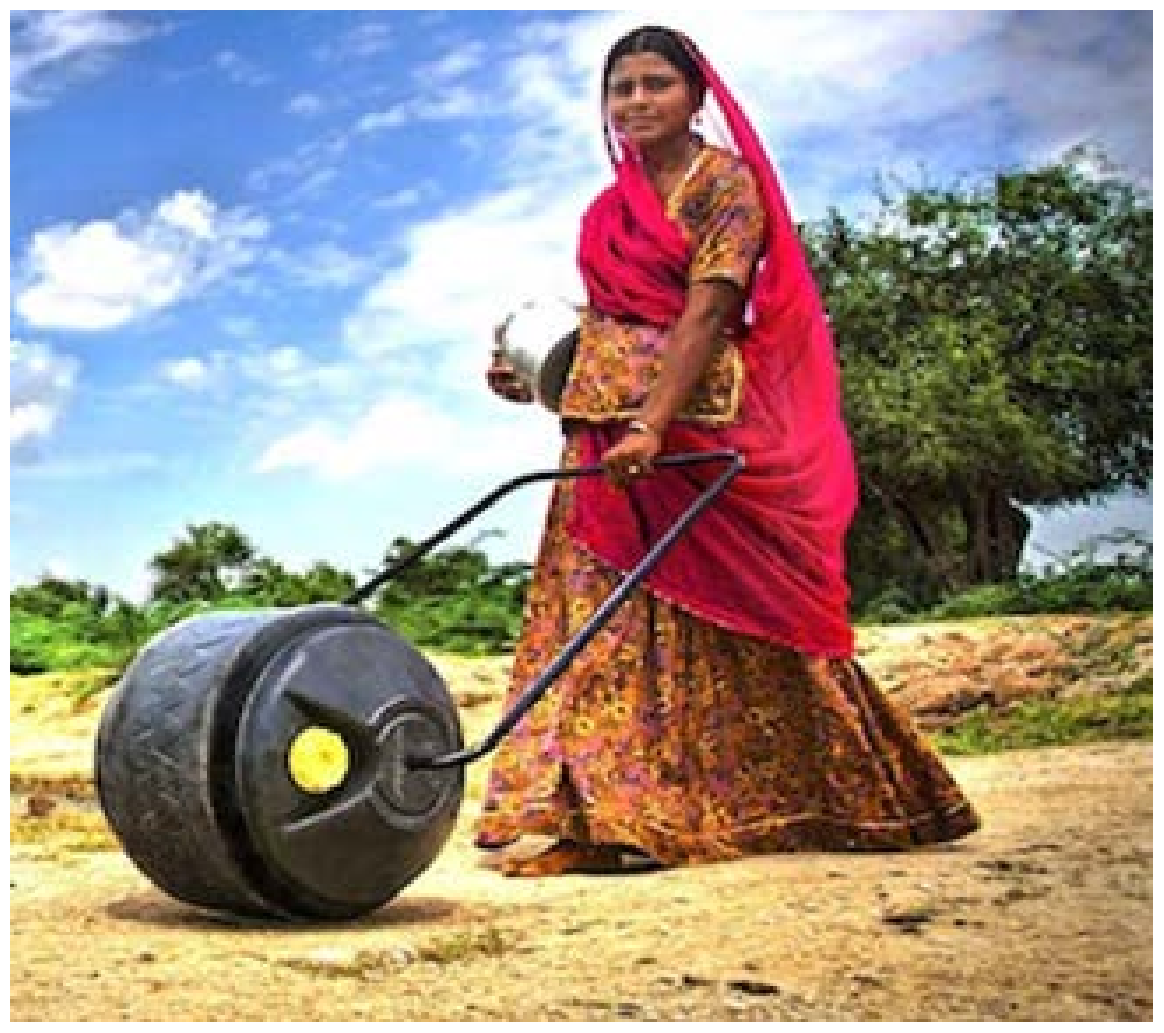

Figure 5. The Wello Water Wheel in India. Source: Wello Water Wheel, 2017. 
poverty alleviation team, the following areas have been identified as high priority neighborhoods to sell the produced wheels or set up the factory: San Juan de Lurigancho, Comas, and Villa El Salvador. These areas were determined by their levels of poverty, health and, most importantly, access to water. There will always be a transitional group of people moving to Lima from the countryside who reside in similar communities and will not be connected to municipal water lines. This technology will serve them. Having Water Wheels on the market gives such residents access to water before official water infrastructure is built.

The Water Wheel provides immediate social benefits. Wello found that the users of their products had more time for child care, educational attainment and employment. Other potential customers may be farmers who could use this product as a water jug, which could then be connected to an irrigation system. More jobs and more free time for women mean that serious economic benefits, alongside water access, should occur through this project.

\subsection{Capital Costs}

\subsubsection{Education Outreach Program}

This educational outreach program would be implemented just one month before the first grey water pipeline is completed. The expenses are entirely capital costs, and there would be no operation or maintenance costs, unless after five years, the government wants to continue this program, which the authors would recommend. That is, it is assumed that after five years the distributed books would need updating. The costs of this project are twofold: paying for the services of Water for People and printing the educational booklet.

Labor Cost: According to the economics database, Trading Economics, the minimum wage in Lima is $\mathrm{S} / .850$ per month, the average low skilled wage is S/.1590 monthly, and the average highly skilled wage is S/.4190 monthly (Trading Economics, 2017). The water team has determined the Water for People representative should be paid slightly higher than a low skilled worker. With an assumed salary of S/.1620 soles a month, and assuming a 40 hour work week, or roughly US\$ 3 an hour, twenty hours to design and write the lesson book for children, five hours to train farmers, and five hours to train teachers amounts to 30 hours of labor at a total cost of S/.291.55 or US\$ 90 . These assumptions are very conservative, and the labor cost could easily double or triple due to many more hours possibly being necessary to train the number of farmers and teachers active in the project.

Printing Cost: The team was unable to determine the exact number of Lima's citizens who are aged ten and eleven. However, there are 2,384,859 people aged zero to fourteen years old (World Atlas, 2013). Assuming that the fifteen different ages are equally distributed, 2,384,859 divided by 15 is roughly 158,990 160,000 in this age group. Thus, it was determined to print 160,000 copies of the booklet for students in Lima. To print a twenty page, full color booklet with a thick laminated, glossy cover would cost US\$25,280 for 160,000 booklets (Daz- 
zle Prints, 2017).

To summarize, with a labor cost of US\$ 90 and a printing cost of US\$ 25,280, the total cost of the project would be US\$ 25,370. Water for People would pay $40 \%$ of the total, or US\$10,148 (S/.32837.22), and the City of Lima would pay $60 \%$, or US\$15,222 (S/.49256.16). That is, the total cost of the project to Lima for educating the population on water best practices would be only a little more than US\$15,000.

\subsubsection{Water Wheel}

The water team considers the Water Wheel project as a high priority undertaking, and it should be implemented within the first year of the proposed 5-year environmental plan. The total cost to implement the Water Wheel project has been estimated at $S / .647,760$ (US\$200,000). The total cost includes the investment necessary to establish the project as well as operation and maintenance expenses. The estimated foreign currency cost of studies has been estimated at US $\$ 160,000(80 \%)$, while the additional cost of studies in local currency is expected to be $S / .129,552$ (20\%).

Labor Cost: The proposed Water Wheel project would require somewhere between fifty to one hundred employees to manufacture the wheels and operate the project. The water team has estimated that project employees would be paid S/.1620 per month for a 40 hour work week (S/.1620 / (4 weeks x 40 hours), or US\$ 3 an hour.

Construction Cost: For this project, the team proposes a manufacturing site that would also serve as the distribution location. In order to do so, $10 \%$ to $15 \%$ of the site would be utilized as retail space, and the rest of the site would be dedicated to the manufacturing of the Water Wheel. Depending on the site location, the cost to build the manufacturing and distribution site would be between 10 to 25 US dollars per square meter. Assuming that the cost per square meter is US\$ 10 and that the site would cover roughly $9290.304 \mathrm{~m}^{2}\left(100,000 \mathrm{ft}^{2}\right)$, the proposed Water Wheel project would cost an estimated US\$ 1 million to construct. Assuming this cost is equally distributed over the 5-year span of the environmental plan, the annual construction cost would be US\$200,000.

\subsection{Timing: 5-Year Implementation Schedule of Projects}

\subsubsection{Community Education Outreach}

The timing of the community education outreach efforts would coincide with the grey water pipeline project discussed in the preceding sewage and sanitation section. The water team has determined that the farming best practice presentations would be most helpful to the community if presented right before the grey water pipeline construction is completed in each neighborhood. These presentations would almost be a celebration of pipeline completion. The grey water pipeline leads to four farming areas within three phases: Phase 1. Carabayllo, Phase 2. Chaclacayo and Ate, and Phase 3. Pachacama. The costs are summarized in Table 2. 
Table 2. Community education outreach implementation.

\begin{tabular}{cc}
\hline Timeline & $\begin{array}{c}\text { Community Water Education } \\
\text { Outreach Implementation Plan }\end{array}$ \\
Week 3 & Draft, print and ship booklets for school children \\
Week 8 & Booklets are distributed to teachers at five training sessions \\
18 months & Carabeyllo pipe completed, first farmer presentation \\
$(1.5$ years $)$ & Chaclacayo and Ate pipe completed, second farmer presenta- \\
36 months & tion \\
$(3$ years $)$ & Pachacama pipe completed, third farmer presentation \\
54 months & \\
\hline
\end{tabular}

Source: Author.

\subsubsection{Water Wheel}

For the 5-year period of the environmental plan, the Water Wheel project has been broken down into several phases of implementation, which is outlined in Table 3. The main focus of the first year of this project would be to conduct the necessary research to ensure the effectiveness of the project and to perfect its design. During this time, there would also be a site-selection study to determine the optimal location for the factory and distribution site. Year 2 would include a 6-month construction period to build the factory, while the remainder of the year would be used to perfect the assembly line by piloting production of a limited number of Water Wheels per day.

Years three through five would increase incrementally the scale of production to suit market demand and production capability. Referring to the Wello project discussed earlier in this section, organization officials set a goal to distribute 10,000 products to reach 80,000 families. Thus, the water team intends to replicate Wello's earlier, successful scaling model. Often when scaling production up to full capacity too quickly, the products are not manufactured correctly, and investment is wasted. By year five, when production would be at full capacity, the water team estimates that 50,000 Water Wheels produced would assist 400,000 families in need of water.

While recognizing the intensity of the water crisis in Peru, one must remain optimistic as all of the projects presented here are politically and financially achievable. The grey water pipeline (in collaboration with the sewage and sanitation team), community water conservation education, and drip irrigation (collaboration with the industry team) would increase the efficiency of Lima's scarce water supply, while empowering farmers to save money on water costs and produce a larger crop. The water conservation education unit in Lima's public schools would slowly spread water knowledge. When Lima residents as a whole understand irrigation, climate change, grey water use, and water best practices, they would be equipped to use water more effectively. The Water Wheel program would create 50 to 100 local jobs and serve as a flexible way to transport 
Table 3. Water Wheel implementation plan.

\begin{tabular}{|c|c|c|c|c|}
\hline Year 1: & Year 2 & Year 3 & Year 4 & Year 5 \\
\hline $\begin{array}{c}\text { Identify and target high impact } \\
\text { consumers }\end{array}$ & $\begin{array}{c}\text { Construct } \\
\text { manufacturing } \\
\text { distribution site for } \\
6 \text { months }\end{array}$ & $\begin{array}{l}\text { Small scale } \\
\text { operation }\end{array}$ & $\begin{array}{l}\text { Medium scale } \\
\text { operation }\end{array}$ & $\begin{array}{l}\text { Full scale } \\
\text { operation }\end{array}$ \\
\hline $\begin{array}{l}\text { Validate the appropriateness of the } \\
\text { design }\end{array}$ & $\begin{array}{l}\text { Scale manufacturing } \\
\text { capacity }\end{array}$ & $\begin{array}{l}\text { Produce } \\
\text { 10,000 Water } \\
\text { Wheels }\end{array}$ & $\begin{array}{l}\text { Produce } \\
\text { 25,000 Water } \\
\text { Wheels }\end{array}$ & $\begin{array}{l}\text { Produce } \\
50,000 \text { Water } \\
\text { Wheels }\end{array}$ \\
\hline $\begin{array}{l}\text { Determine willingness to pay, and } \\
\text { site-selection study for } \\
\text { manufacturing/distribution centers }\end{array}$ & $\begin{array}{l}\text { Develop systems to } \\
\text { enable efficient and } \\
\text { effective operation }\end{array}$ & $\begin{array}{l}\text { Impact: } 80,000 \\
\text { families }\end{array}$ & $\begin{array}{l}\text { Impact: } \\
200,000 \\
\text { families }\end{array}$ & $\begin{array}{l}\text { Impact: } \\
400,000 \\
\text { families }\end{array}$ \\
\hline
\end{tabular}

Source: Author.

water to settlements, which are not yet connected to city lines. Desalination is a project currently being pursued by Lima. However, the government should consider policies, which foster a successful environment for desalination growth in the future. Lastly, one cannot ignore the pollution, corrupting what little water there is. The water team believes this 5-year plan would put Lima on a resilient trajectory within its larger-scoped water policies described in the Robust Decision-Making in the Water Sector: A Strategy for Implementing Lima's LongTerm Water Resources Master Plan (Bonzangio et al., 2015).

\section{Energy}

\subsection{Background}

Peru's energy sector is divided between private and public entities. The Ministerio de Energía y Minas-MINEM (Ministry of Energy and Mines) is Peru's government agency responsible for promoting the sustainable development of mining and energy activities in the country, which includes creating competitive conditions for private investment and environmental regulation (Ministerio de Energía y Minas República del Perú (MEM Perú), 2017). MINEM is also responsible for awarding contracts for projects and helping with funding. In May 2017, 49 out of 70 projects pertaining to the electrification of Peru were completed, making the Ministry of Energy and Mines one of the highest level government compliance agencies (Ibid.).

Italian-owned Enel Distribution Peru is one of the top private entities in both energy generation and distribution throughout the country and has completed energy projects throughout Peru. This company holds the public electricity service concession for the northern part of Metropolitan Lima, the Constitutional Province of Callao and the provinces of Huaura, Huaral, Barranca and Oyón. Its concession area covers 52 districts where it is the exclusive distributor. It covers an area of $1517 \mathrm{mi}^{2}$ and has 1,336,610 clients (Distribution in Peru, 2015).

Finally, it is important to note that the Government of Peru has created a plan for its energy future called The National Energy Plan 2014-2025 implemented by the Ministry of Energy and Mines. This plan outlines certain goals and strategies 
for solar, wind and a zonal study of river basins. It is a rigorous plan that has made clear that MINEM indeed needs to diversify Peru's energy goals (Peru's Energy Future, 2017). The recommendations made later in this section outline strategies for Lima to achieve these energy diversification goals.

The current state of energy in Lima is rather good since Peru has an excess of energy supply. At the current rate of use, the City of Lima is projected to have more than enough reserves to support the current population in the near future. According to a BNP Americas study titled, The Perils of Plenty in Peru's Energy Sector, "....unless power consumption explodes overnight, Peru should be able to cover its electricity needs over the next decade with the generation projects already under construction in the country" (Intelligence Series, 2017). However, as urbanization progresses and climate change continues to affect the region, it is in the best interest of Lima and the region to consider alternative energy sources (Ibid.).

Nevertheless, the lack of access to energy is a major concern for Lima. As stated in the poverty alleviation section there are certain areas throughout Lima that have only limited electricity access. Two of the main areas of concern are the districts of Comas and San Juan. This is due in part to living on the remote outskirts of the city along the mountainside. During the December 2015 UN Climate Change Conference, it was made clear that energy consumption and electricity generation together improve the lives of people. Since then, there have been plans to fix the rural electricity gap by 2020 (Enel, 2017).

\subsection{Problem Statement}

Peru adopted its current national energy plan in 2014. It is a 10-year plan for the years 2014-2025 that lays out steps to contribute to the fight against climate change. The goals of the plan are to reduce environmental impacts, improve equity in access to energy, strengthen the use of renewable energies and secure the sustainable development of the country.

In the past decade, Peru has realized the evidence of climate change more so than other countries. The country has been listed as number ten among the countries most vulnerable to climate change (The World Bank Group's Peru Portfolio, 2015). According to Gustavo Meza-Cuadra, Peru's Representative to the United Nations, Peru is one of the countries that are already affected by climate change; he cites deforestation and forest degradation in the Peruvian Amazon and receding glaciers in the Andes (United Nations, 2014). This damage is threatening the people of Peru, and Meza-Cuadra warned of climate change threatening to affect access to drinking water and electricity for Lima's residents, much of which is generated from hydroelectric power (Ibid.).

\subsection{Priorities}

According to the Ministry of Energy and Mines, energy demand in Peru is projected to grow at $10 \%$ annually. It is estimated that in 2017 , total required energy capacity will increase to almost $8 \mathrm{GW}$, which would require significant invest- 
ment in power generation (CINDYE, 2011). Depleting oil and gas resources are a major concern and have contributed to the growth of renewable energy investment (Ibid.). With the potential for climate change to reduce urban use of hydropower, Lima should look toward renewable energy sources. Currently only $.65 \%$ of wind potential, $6.1 \%$ of biomass potential, and less than $1 \%$ of solar potential is being exploited (Ibid.). With potential impacts to hydropower and natural gas, both Peru and Lima have initiated plans to research other options. According to the National Energy Plan 2014-2025, 6\% of total energy generation is set aside for renewables (Tejerina, 2015).

\subsection{Proposed Projects}

Based on the previous explanation of political characteristics and the reality of excess energy, the energy team proposes a series of options to diversify the energy sector. For the long-term sustainability of Lima, the team proposes four options to assist in the long-term management of the energy sector of the city. The projects proposed are in support of the above mentioned goals outlined in the Energy Plan of Lima 2014-2025 (Peru's Energy Future, op. cit.). Additionally, the energy team supports the energy needs of slum neighborhoods outlined in the poverty alleviation section of this article.

First, a large solar array on a mountain range between the two poor, low-income neighborhoods of Comas and San Juan is proposed. The goal of this array would be to provide energy for both neighborhoods. However, during the 5 -year planning period of this project, it would focus on the neighborhood of Comas as a pilot and then extend that energy supply to San Juan based on the success of the first project. Second, a training school is to be included to teach and train women in the neighborhood how to build and maintain these solar panels. Third, a small biomass plant would be constructed. Fourth and finally, a Pilot E-bus system is proposed.

\subsubsection{Large Solar Array}

Peru, as a country, is a leader in the field of sustainable energy. As mentioned above, Peru hosted the 2014 UN Climate Change Summit and has become a leader in the consideration of climate change concerns (Noticias|Agencia Andina, 2017). Additionally, Lima is under threat from some of the largest climate change concerns (USAID, 2017). According to their National Energy Plan 2014-2025, as a country and city, they have committed to exploring the diversification of their energy profile, looking into wind, solar and biomass (Peru's Energy Future, op. cit.). In compliance with their energy goals and plan, the energy team proposes a large solar array on a mountain near the neighborhood of Comas (Enel, 2017). Solar energy is a resource with high potential for the residents of Lima and, specifically, the neighborhood of Comas. Table 4 outlines the funding strategy for the completion of this project. For further information on the government funding portion of this strategy, please refer to the finance section of this article. 
Table 4. Large solar array.

\begin{tabular}{cc}
\hline Total Cost (in US\$) & $\$ 100$ million \\
\hline Government Financing & $\$ 31.2$ million total \\
& (assumed $1 / 3$ from Lima Energy Budget) \\
Foreign Aid: & $\$ 6.24$ million/year \\
& Bank of China: $\$ 32$ million in green bonds \\
Additional Aid: & Santander: $\$ 32$ million \\
\hline
\end{tabular}

Source: Author.

The location of Comas has been chosen strategically as it aligns with Lima's goal of full rural electrification by 2020 (Peru aims to cover the electrical gap with solar panels by 2020 2017). This also aligns with the overall strategy of these authors to have cooperation between the array and the community. This is explained further below. The desire to locate the array here is because of its location between two significant slum areas, Comas and San Juan de Lurigancho. This mountain area is well positioned to access energy and provide for both of these districts. The phasing of this project is intended to be five years.

This plant would be a public/private partnership with the Italian company Enel (Mahapatra \& Mahapatra, 2017). Enel is currently the largest stakeholder of energy in Lima, has established relationships with government partners and runs the electrical grid of the city. Enel currently owns and operates four hydroelectric plants and two natural gas plants.

This proposed plant would serve 100,000 homes each year over ten years: 35,000 in the first five years and 65,000 in the second five years. This would generate a production rate of $200 \mathrm{GWh}$ per year for Comas and avoid approximately 123,000 tons of carbon emission per year into the atmosphere (Ibid.). This level of projected generation will diversify home energy use for these residents.

The overall financial cost of a solar power plant compared to a coal power plant is significantly lower. In fact, the estimated costs of building new coal plants have reached US\$ 3,500 per $\mathrm{kW}$, without financing costs, and are still expected to increase further, meaning a cost of well over US\$ 2 billion for a new $600 \mathrm{MW}$ coal plant when financing costs are included (Synapse, 2008). The solar option for Lima would not only save the city money, but it would also have long-term environmental benefits.

\subsubsection{Co-Op/Education}

The overall goal of the projects presented in this section is to provide a pathway to the long-term sustainability of the region and help achieve Peru's energy goals. For this to be successful, the education of community residents about the importance of energy is critical. Additionally, there are opportunities for workforce development and long-term career advancement.

Thus, a project to create a training school at the solar array is important. This 
model of training would be aimed at the inhabitants of Comas who would be trained on the daily operation, construction and maintenance of the solar arrays. Furthermore, this school would give preference to low-income individuals to support their economic well-being. This proposal has been previously executed by Enel in other Latin American countries, and the costs of this project in Lima are presented in Table 5. For Enel, this is called a Shared Value Model. The model shows that individuals who are given proper training and attention have the capability to use the tools of modern technology and provides long-term career sustainability, as well as self-reliance, for residents of these communities.

\subsubsection{Landfill Attached Biomass Plant}

Biomass plants are another type of renewable energy generation that has been a focus for Peru. Biomass is a renewable energy source from living or recently living plant and animal materials, which can be used as fuel; an example of biomass is plant material that produces electricity with steam (Corporate Vattenfall, 2016). Lima faces a growing concern for landfill waste and trash. Some communities are either living on current landfill sites or in close proximity. This has led to a growing health concern of residents. According to 2013 data from the World Health Organization, Lima produces 8200 tons of trash a day (WHO, 2013). This is an opportunity for a biomass plant to use the waste as a viable resource.

The location of the biomass plants would be related to the previously mentioned areas of concern in Lima; i.e., Comas and San Juan. A site would need to be chosen for implementation after agreement among stakeholders. Enel currently has a stake in biomass plant implementation throughout Latin America. It would form a public/private partnership with the Ministry of Energy and Mines.

In order to keep costs down, the energy team proposes to attach a biomass plant to an existing landfill. This would cost around US\$ 15 million. A biomass plant this size could generate $50 \mathrm{MW}$ to power around 18,000 homes. For further information on the government funding portion of this strategy, refer to the finance section. Total costs are summarized in Table 6.

This project would cost approximately US\$ 3 - 5 million a year to operate, for the first two years of this project. The following three years of $\mathrm{O} \& \mathrm{M}$ would average around US\$ 2 million a year. This amount would be shared by Enel and the Peruvian government.

\subsubsection{Electric Bus Fleet Extension}

The last project is one that will be an extension to an electric bus project already

Table 5. Solar training school.

\begin{tabular}{cc}
\hline Total Cost (in USD) & $\$ 50,000$ \\
\hline Government Financing & $\$ 5$ million \\
Fully Funded & \\
\hline
\end{tabular}

Source: Author. 
Table 6. Biomass plant.

\begin{tabular}{cc}
\hline Total Cost (in USD) & $\$ 15$ million \\
\hline Government Financing & $\$ 10$ million from the Peruvian Government \\
Foreign Aid: & $\$ 5$ million (Enel) \\
Additional Aid: & None \\
\hline
\end{tabular}

Source: Author.

being implemented. Currently Enel and the Global Sustainability Energy Partnership (GSEP) are working within Lima to create additional transportation access. Their goal is to create an electric bus fleet that will serve communities that are currently lacking efficient transportation options.

Developing an Electric Transportation System (ETS) is among the Peruvian Government's commitments against climate change, and this project has high replicability (CINYDE, 2011). Again, the energy team's focus is on the previously stated focus areas, Comas and San Juan. This project will be solely a private partnership between ENEL and the GSEP. Enel would lead the project and contribute the large sum of US $\$ 4$ million in the five-year period, while the smaller entity GSEP would contribute about US $\$ 1$ million. Because the roads are already in place, no funds for construction would be needed. The costs of the project would include purchasing the electric buses and their yearly operation and maintenance. In the industry section of this article, an Electric Bus Assembly Plant has been proposed. This project would create a center where Enel and the GSEP could purchase electric buses. The plant could also make it possible for the upfront cost of an electric bus to decrease, which could allow Enel and the GSEP to purchase an additional bus or two in later years. The initial year would see the purchase of the bus fleet at around one million dollars for 2 - 3 electric buses. Each 12-meter electric bus would cost around US $\$ 300,000$ so a budget US\$1 million would allow for three buses to be purchased. The next four years of the 5 -year plan were budgeted to account for the operation and maintenance costs of the bus fleet. The cost each year for O \& M would also be approximately US $\$ 1$ million split between Enel and the GSEP. Project costs are presented in Table 7.

\section{Transportation}

\subsection{Background}

Lima derives its name from the Rímac River on whose south bank it was founded as a modern oasis situated in the coastal desert at the foothills of the Andes Mountains. This capital city of Peru has three major modes of public transportation, with a cable car system under consideration. There is a subway system running along a single $21 \mathrm{~km}$ line serving 16 stations, all above grade, in view of Lima being in a seismically active region. Five more lines are in various stages of consideration and implementation, of which Lines 2 and 4 are expected to be completed soon. In addition, a Bus Rapid Transport (BRT) system connects north and south Lima, whereas private buses, minivans and cars occupy 
Table 7. Electric bus fleet extension.

\begin{tabular}{cc}
\hline Total Cost (in USD) & \$5 million \\
\hline Government Financing & N/A \\
Foreign Aid: & \$4 million (Enel), \$1 million (GSEP) \\
Additional Aid: & N/A \\
\hline
\end{tabular}

Source: Author.

the road network. Bike lanes are situated mainly in the historic core, while most freight transport is by sea (Yachiyo Engineering, 2005).

The BRT system, popularly known as the Metropolitano has two services: a trunk service and a feeder bus service. The trunk service runs north-south connecting Barrano, Miraflores, San Isidro and Lince with the city center and further with Independencia in the north. It was inaugurated in 2010. Regular buses stop at every one of the 37 stops, while an express bus service makes selected stops and is suitable for long distance trips. The bi-articulate buses have 120 seats and arrive every 5 minutes. Together, they serve 650,000 passengers daily. A bus card costs S/.4.5, while single fares are S/.2.5 each. The Metropolitano feeder bus service originates from the end terminals and selected stops in between. These smaller buses of 40 or 80 seats ply regular routes serving neighborhoods around the end terminals of Chorrilos and Independencia, and cost S/.0.5 per trip. Feeder buses also ply seasonally from more intermediate stops, especially near the center for promoting tourism (Ibid.).

Combi buses, omni buses and microbuses together account for more than $47 \%$ of daily trips in Lima. In 2008, there were 322 transportation companies operating nearly 30,000 buses on 424 bus routes. Private taxis account for $4 \%$ additionally. 16.9 million trips are taken every day, $20 \%$ of them in private cars, $1 \%$ by bicycle and motorbike, and $79 \%$ using the public transportation system, where the distribution breaks down to $65.2 \%$ on the conventional bus system; $1.6 \%$ on the Metropolitano; $0.4 \%$ on the L1MLC; $11.3 \%$ by taxi and motorcycle taxi, and $0.5 \%$ by truck and other means. The buses operated by private enterprise account for $45 \%$ of all fatal accidents on roads. The conventional public transportation system has operational limitations such as oversupply due to an excess of bus routes, high costs due to the lack of more efficient operations, limited reliability, absence of defined stops, inadequate vehicles, low maintenance levels, high accident and pollution rates and a minimum level of user comfort. From a sustainability point of view, that only $16.5 \%$ families in Lima own a private car and $30 \%$ own a bicycle, is encouraging. However, existing bike lanes are mostly in the city center and the core historic city. They generally serve places of touristic importance. The subway stations have bike-parking facilities, and terminal stations of the BRT harbor the rest. $126 \mathrm{~km}$ of bike lanes are already in place (Ibid.). 
The last decade has seen rapid urban expansion in Metropolitan Lima. Unorganized development has led to severe socio-economic issues, such as unequal spatial urban development, land and housing shortages and pressure on existing infrastructure, all of which are exacerbated by a lack of appropriate sustainable urban services. As always, the brunt is borne by low-income families plagued by stagnant wages and unemployment. They are pushed to the ever-receding periphery of the city and the hills, where the cost of living is less. However, public transport fails them, for low frequency, longer travel times and a precarious road infrastructure make transport unreasonably taxing on family income.

The population is largely concentrated in residential districts on the periphery. The hills of Ventanilla, Comas and San Juan de Lurigancho in the north are populated by the poor and the middle class, whereas, Miraflores, Chorrilos and Villa el Salvador comprise the more affluent neighborhoods in the south. Public transport mainly fails the poor neighborhoods in the hills. Except for the cable car project now under consideration, no public transport system serves the

hills. Bicycles and private mini vans serve these communities. Lack of proper paved roads and a basic public infrastructure in general furthers their social alienation and economic poverty (Barbier, 2012).

\subsection{Problem Statement}

\subsubsection{Poor Neighborhoods in the Hill}

Driven by poverty and lured by the low cost of living in places un-serviced by public infrastructure, poor people slowly climbed up the mountain slopes. Shantytowns, featuring construction of cardboard, tin, cans and wicker, now form a unique townscape upon the slopes of the hills.

\subsubsection{Terrain versus Ring Roads}

The hill chains surrounding Lima separate urban form as fingers reaching for the sea. The counter form, that is, the urban populated valleys, stay distinct, and are accessible from the central core alone. As of now, to travel from Comos to San Juan de Lurigancho, it is necessary to travel through Independencia and Rímac, and cross over near El Augustino to enter San Juan de Lurigancho. This is problematic, for it leads to a bottleneck for land transportation, limited by the terrain. Central Lima thus stays congested, and traffic jams are common, especially during the rush hours. Moreover, road infrastructure up the mountain slopes is poorly developed, with paved roads being absent for the most part. (Lima Traffic Pattern, 2017).

\subsubsection{Private Vehicles, Pollution and Inefficiency}

According to the Ministry of Transport and Communications of Peru, "there is an excessive number of mass transport units, 25,874 vehicles in total, and an oversupply of taxis, 250,000 units when it should have half" (World Justice Project, 2017). In addition, a study done by Metropolitan Lima cited, "the lack of promotion for the development of alternative small scale mobility systems, such 
as bicycles and pedestrian infrastructure" (Ibid.). An increasing number of private vehicles leads to traffic congestion, with slow moving traffic affecting the environment through increased pollution. This may be caused primarily by factors such as the limited transportation options of a single lane Bus Rapid Transit system. Statistics show that there are approximate 31,000 buses, microbuses, and vans operating in Lima and Callao, most of them 15 - 20 years old, on more than 560 routes that generally lack public transport facilities such as bus lanes, terminals and proper stops. Thus, private vehicles share the road with the public vehicular systems, leading to traffic congestion which impacts time, cost and pollution levels (Yachiyo Engineering, op. cit.).

\subsubsection{Lack of Modal Integration}

One major contributor to Lima's congestion is the lack of model integration between the bus, BRT, and subway systems. Lima residents have to carry two fare cards for two systems. The city has an integration plan created, but political and economic forces have delayed its implementation. The completion of the plan will improve the management of the system, integration of the system, and how citizens of Lima view public transportation (Urban Conceptual Authority 129, 2017).

\subsubsection{Bus Stops}

Research by the Harborview Injury Prevention and Research Center (2017) has found that, intersections with bus stops were 3 times more likely to have a pedestrian vehicle collision, relative to intersections without bus stops. The highly competitive environment among bus companies provides an economic incentive to risky practices such as dropping off passengers in the middle of traffic and jockeying for position with other buses. Bus bays are not used safely by leaving and entering traffic, as intended by city planners. Increased risk for pedestrians is an unintended consequence of dedicated bus areas, when there are strong economic incentives for picking up passengers whenever possible, with limited law enforcement.

The bus stops at intersections are almost always located on the near side, approaching the intersection, rather than being positioned on the far side. Moreover, bus drivers under pressure to complete their routes quickly, pick up as many passengers as possible, and work long hours with few and short rest periods. They prevent competitors from overtaking them by blocking traffic, and use the phased signal traffic to maximize stops. There are few legal consequences of not paying and accumulating traffic tickets (Quistberg et al., 2015).

\subsubsection{BRT Lane Segregation}

The BRT lanes do not have convincing physical barriers that separate them from other traffic, not just in between stops, but also at the bus stops themselves. At mid-block sites, bus stops on a dedicated bus transit lane were also associated with collision risk. Privately operated buses and mini-vans provide last mile 
connections from these bus stops. The passengers getting off the BRT, cross over the BRT lane to reach these awaiting buses and vans in the main traffic lanes, becoming a major cause for accidents. The lack of pedestrian bridges at the bus stops that serve large crowds increases signal time on major arterial roads and make them more prone to accidents. Because of the lack of a physical barrier, private vehicles often enter BRT lanes, especially in stressful traffic, making the BRT redundant (Ibid.).

\subsubsection{Bike Lanes and Parking}

An ideal transport system for Lima would provide affordable, convenient and enjoyable door-to-door trips, reducing monetary costs and time while improving comfort. Thus, non-motorized transport is most promising, whenever possible. It is encouraging that in Lima only $16.5 \%$ households have a car, while $30 \%$ own at least one bike. Moreover, $126 \mathrm{~km}$ of bike lanes are already in place (Ortegon-Sanchez et al., 2016).

The low-income population does not perceive the benefits of public spending, for they inhabit mostly areas on the hills at the city's periphery, necessitating longer than average travel time and expenses. Situated on steep slopes with inadequate infrastructure for non-motorized modes, they remain poorly connected with limited access to affordable public transport. Bicycles are, no wonder, their most favored option. Nevertheless, the hills have no bicycle facilities, in terms of dedicated lanes, elevators or parking facilities at the foothills. The lanes built are mostly in the city center and historic core, presenting a façade of progressive sustainability for foreign tourists and catering to the elite residents who reside nearby. Limited greenery in this desert landscape leads to little natural shade, making cycling or walking inconvenient during summer, even as the proximity to the Pacific Ocean keeps temperatures moderate throughout the year.

The problems of existing biking lanes in Lima have to do with connectivity and consistency of patterns of travel attraction, and with the existing and planned networks of mass transit, as explained by Ortegon-Sanchez and his colleagues (Ibid.).

\subsection{Proposed Projects}

\subsubsection{Workers' Union}

In February 2016, residents of Manchay, in southwestern Lima, blocked access to roads of their neighborhood, protesting the integrated transport system of Lima's new shuttle buses. While fares of privately owned vehicles, the popular combis that fill in the void, cost US\$ 0.15 , the official new shuttles would cost US\$ 0.35. As Facebook user Lia Valderama put it, "How are you going to increase the fare by more than $100 \%$, and at the same time take away the source of economy, in a sector that survives on transport... no one has the right to introduce reforms that have not first been consulted with the public...". Private transport services are indispensable to Lima, at least in the near future. Instead 
of replacing them overnight using a top-down approach, it would be more prudent for the government to encourage organizing the sector and addressing the issues by reforming their modes of practice. Encouraging workers' unions for drivers and maintenance staff would not only help bring security and fix responsibility, but also endear such workers to the government (Ibid.).

\subsubsection{Emission Standards for Buses and Private Vehicles}

Implementation of a National Vehicle homologation system that includes technical vehicle inspections of buses that would lead to replacing the aging bus fleet, and of private vehicles would be progressively undertaken. This would include a review of emission standards and the introduction of a labelling scheme for energy efficiency and $\mathrm{CO}_{2}$ emissions; that is, retrofitting to upgrade from Euro 3 to Euro 4 for all vehicles to keep up with improving environmental standards. For this to be successful, there should be government subsidies of $50 \%$ of costs to upgrade, and other subsidies for electric and hybrid vehicle ownership to grow.

\subsubsection{BRT Lane Segregation}

Physical barriers that effectively segregate the BRT lanes is an obvious requirement. A call for proposals may help identify clever solutions that would achieve this at low cost quickly. Maintenance of such infrastructure would be of paramount importance, not only to make investment sustainable, but also to keep the lanes safe. Currently, traffic in Lima is chaotic as Figure 6 shows.

\subsubsection{Pedestrian Footbridges}

The BRT and subway stations are scenes of large crowds entering or exiting. These stations are connected to the interior of neighborhoods by private buses and combis, an interchange that is problematic. Pedestrian footbridges at these locations that would connect these stations to secondary bus and combi bays would not only reduce substantially traffic signal times on the major arterial routes, but also reduce accidents. Pedestrian movement would be organized and

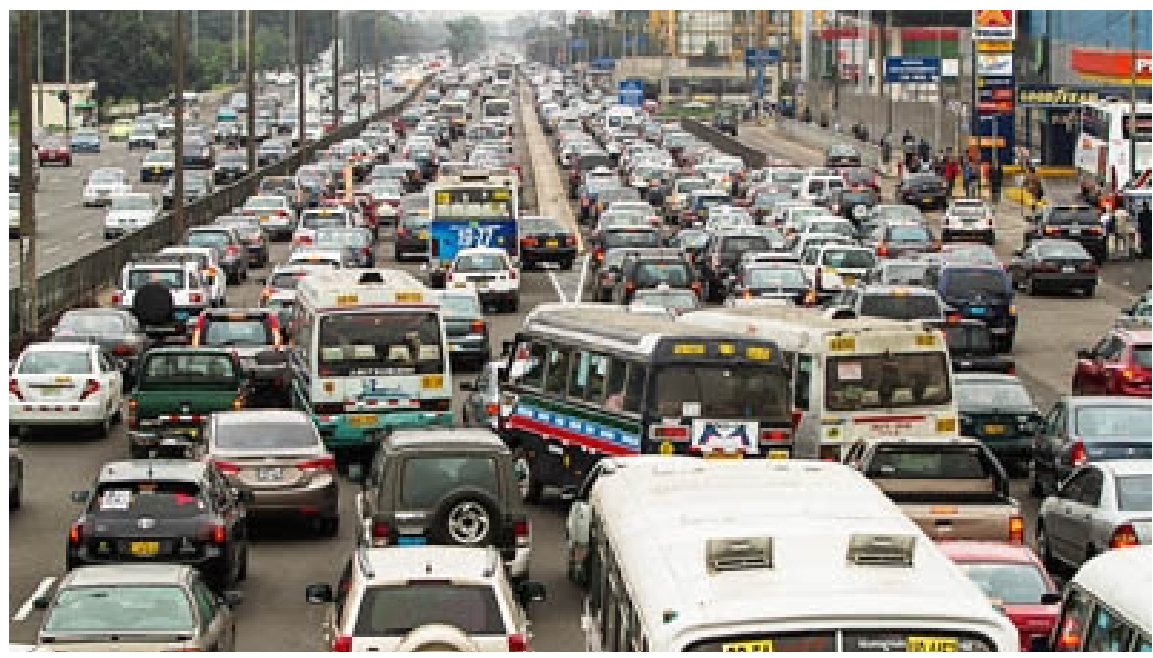

Figure 6. Road traffic in Lima. Source: Fretes-Cibils et al., 2007. 
made safe. Providing elevators and ramps at these bridges would ensure universal accessibility.

\subsubsection{Law Enforcement}

Assuring appropriate road safety by enforcing traffic laws is one of the essential elements of a well-balanced transportation system of any city. Police traffic control and enforcement are measures for quick and relatively inexpensive interventions. Enforcing traffic rules may help in mobility of people and goods and in traffic safety. If traffic rules were followed, a free flow of traffic would ensue, solving one of the biggest traffic problems of Lima.

\subsubsection{Biking Infrastructure}

The city of Lima has more motorized options than sustainable means of transport. Due to the lack of adequate infrastructure, legislation and general cycling culture, cyclists remain a discriminated group of users without legal tools to defend their rights. For the development of a sustainable city, the development and implementation of a cycling system is crucial. Although there is growing demand for the use of bicycles in the city, a policy push is essential, aimed at promoting the use of bicycles (World Justice Project, op. cit.).

\subsubsection{Cable Car}

Two cable car lines have been proposed for Lima. The first one would connect Independencia with San Juan de Lurigancho, in North Lima. It would connect Naranjal station of the Metropolitano BRT to the San Carlos station of the Lima subway. It would cover $6.08 \mathrm{~km}$ to serve five stations in 25 minutes, compared to a 1 to 2-hour trip required now. It would cost US\$51 million, bidding for which was done in October 2015, and construction began in 2017. A second line serving the El Augustino district would connect Cuartel Barbones military base to a final station between Nicholas Ayllon Avenue and the Via de Evitamiento highway. It would require US\$33 million, travelling $3.84 \mathrm{~km}$, serving four stations in 15 minutes. The government estimates these Gondolas would serve 84,000 of the poorest residents in the hills for a fare between US $\$ 0.05$ and US $\$ 0.06$ (Yachiyo Engineering, op. cit.).

\subsubsection{Capital Costs}

The estimated prices for the projects noted above are summarized below:

Project 1: Fare Integration

- US\$3.3 million for the integration of Lima's fare system including the Metropolitano BRT and Lima subway.

- Integration Study: US $\$ 10,000$

- Total Cost: US\$3.31 million

- Proposed Funding: City of Lima, Federal Government Financing.

Project 2: Cable Car

- US\$ 84.5 million for the construction of a cable car.

- Feasibility Study: US $\$ 500,000$ 
- Total Cost: US\$ 85 million

- Proposed Funding: A public-private partnership (P3), between private sources and investment from the City of Lima and the Ministry of Culture.

\section{Project 3: Pedestrian Footbridges}

- US\$ 1.1 million for the construction of 38 pedestrian footbridges.

- Feasibility Study: US \$50,000

- Total Cost: US\$ 1.15 million

- Proposed Funding: City of Lima Housing and Urban Development Budget (HUD).

\section{Project 4: Bus Stop Redesign}

- US\$ 1 million for the building of 75-100 bus stops at 38 BRT stations.

- Feasibility Study: US\$ 0

- Total Cost: US\$ 1 million

- Proposed Funding: City of Lima.

\section{Finance}

\subsection{Role of the Finance Group}

To ensure the completion of each project proposed by the sectoral teams, it was imperative that many financial considerations were made concerning capital costs, environmental studies, operation and maintenance, interest rates and available funding. It was the role of the finance team to analyze the various projects based on area of impact, number of people affected, total cost of the project, and the level of priority. A thorough analysis of these factors in conjunction with the financial circumstances of each project is what the finance team has used to determine which projects would be selected. The cost for projects selected have been financed using foreign and domestic sources of funding, including foreign direct investment (FDI), foreign aid, development banks, and the City of Lima's debt capacity and mortgage availability. For each project, the financing is assured only for the 5-year period of the environmental plan for Lima proposed in this article.

\subsection{Proposed Projects in the 5-Year Environmental Plan}

The projects outlined hereafter are proposed to alleviate the environmental problems in various sectors of Lima. These have been selected from a larger number of projects that have been considered by the six sectoral teams (i.e., poverty alleviation, industry, sewage and sanitation, water, energy and transportation) during the research and analysis process of developing the 5-year environmental plan for Lima.

\subsection{Process}

The definition of each sector's projects leads to the next step of the process: the funding outlined below. The finance team introduced a funding structure to the sectoral teams that allows each team to go through the process in an orderly 
manner and optimize access to the various funding resources listed in the database.

\subsubsection{Research Process for Foreign Direct Investment}

The finance team examined Foreign Direct Investment (FDI) as part of its research into opportunities for international funding. FDI is defined as an investment made by a company or individual in one country in business interests in another country, in the form of either establishing business operations or acquiring business assets in the other country, such as ownership or controlling interest in a foreign company (Staff, 2015). These investments are determined by the economic and political situation of the country.

According to World Bank data, Peru's GDP in 2013 reached US\$ 201.2 billion. (The World Bank in Peru, 2017), the highest in the history of the country. The GDP growth in the following years will remain steady, reaching US\$192.1 billion dollars (Ibid.). However, the FDI in Peru gradually declined between 2012 and 2017, reaching US\$ 4.8 million dollars in 2017, while it represented US\$ 12.2 million dollars in 2012 (Foreign Direct Investment, n. d.). The finance team identified the following countries that invested directly in Peru in the past five years.

\subsubsection{Research Process for Foreign Aid}

The second step into the process for funding research was to focus on the definition and sources of foreign aid. The Development Assistance Committee (DAC) of the Organization for Economic Cooperation and Development (OECD), defines foreign aid (or the equivalent term, foreign assistance) as financial flows, technical assistance and commodities that are (1) designed to promote economic development and welfare as their main objective (thus excluding aid for military or other non-development purposes); and (2) are provided as either grants or subsidized loans (Radelet, 2006). Many projects taking place currently in Peru and Lima are funded by foreign aid from several countries. The finance team determined the country's partners, the sector or sectors relevant to each partner, and their related foreign aid agencies. The foreign aid agencies and development banks cited in this report are the ones related to project's sectors: energy, water, sewage and sanitation, poverty alleviation and industry. The World Bank contributed in Peru to funding water management, the reduction of vulnerability to natural disasters, SIT (System Integration Testing) development, public transportation, water and sewerage, education and agriculture. Japan International Cooperation Agency (JICA) took part in housing reconstruction, flood protection, water supply and sewerage, children's nutrition and TV broadcasting. The French Development Agency (AFD) subsidized public transportation, low income housing, and environment related projects. USAID, the lead US government agency assisted poverty alleviation and inequality, combated narco-trafficking, mediated social conflicts and managed-environmental threats. Aside from foreign aid agencies, Peru received subsidized loans from National 
Development Banks (NDBs), considered as key in mobilizing private sector funding to close the finance gap to reach the Sustainable Development Goals (The World Bank in Peru, op. cit.). The Inter-American Development Bank (IDB) is the main multilateral lender in Peru, with a US\$ 1.41 billion dollars of total loans (Peru and the IDB, n. d.) dedicated mainly to transportation, health, modernization and reform of the state, water and sanitation, flood control and storm drainage, fiscal management, climate change, education, urban development and housing. The Development Bank of Latin America (CAF: Corporación Andina de Fomento), a regional development bank created by 18 South and Central American countries, approved in 2012 a total budget of $\$ 1.7$ billion dollars (Countries - Peru - Our Action, n. d.), for operations related to irrigation projects, tourism projects, development of indigenous communities, water treatment and climate change. Kreditanstalt für Wiederaufbau (KfW), a German development bank, granted funds to Peru to promote renewable energy, water supply and wastewater disposal and good governance. The China Co-Financing Fund for Latin America and the Caribbean, under the management of IDB, contributed to poverty alleviation and public transportation. Funds and subsidized loans attributed to these organizations and institutions contain conditions and objectives that must be met by Peru.

\subsubsection{Determining Lima's External Debt}

Peru was one of the first countries in Latin America to make its Integrated Financial Management Information System (IFMIS) available to the public through its fiscal transparency portal (Seguimiento de la Ejecución Presupuestal (Consulta Amigable), n. d.), where users can find budget and execution data on a yearly, monthly and daily basis (The World Bank in Peru, op. cit.). Thus, IFMIS makes information regarding Peru's budget easily accessible. External debt in Peru is projected to be US\$ 76.18 million by the end of the $1^{\text {st }}$ quarter of 2018, according to Trading Economics global macro models and analyst expectations (Peru Total Gross External Debt Forecast, n. d.).

Peru's capital Lima had in 2009 a debt of S/128,171,358, equivalent to US\$ 42,723,786, while Peru's gross external debt in the same year represented US 35 billion. Between 2009 and 2017, the total gross external debt grew by a ratio of 2.18 (Ibid.). As of 26 October 2017, at the 30-year US treasury rate of $2.96 \%$, the annual maximum debt capacity of Lima would be around US\$ 1 billion.

Regarding the funding allocated for the development of each project, the finance team assumed that the city of Lima would have to account for $20 \%$ of the cost of each project. If $20 \%$ of each project's budget, once summed up, exceeded Lima's budget for each year, the remainder should be accounted for as debt, and the debt should not exceed the total amount mentioned previously.

\subsubsection{The Grant Application}

Due to limited resources, the finance team set up a grant application to be com- 
pleted by each for each project in order to understand the size, the location, the cost and the length of all projects. The grant application process allowed the finance team to envision the project's impact area and, thus, the targeted population, in order to prioritize projects. The grant application was also a way to develop an overview of the projects, and to identify any correlation between projects from different sectors, and the impact of these correlations on the total budget, to identify any possible overlap, and to prevent cases of double funding. The grant application further contained a comments section, where each team was able to advocate for their projects. They could answer questions such as "Why precisely this project?", "What would it improve in Lima?", "Is Lima already implementing a similar project?", and "Why should the finance team allocate funds to this project?" The answers to these questions affected considerably the funding decisions regarding each sector's projects.

Overall, the grant application table presented in the next section of this article is an evaluation grid to assess each project's priority and importance under the current socio-politico-economic climate of Lima, to establish the city's environmental roadmap for the next five years.

\subsubsection{Prioritization of Projects}

As mentioned previously, it is not be possible to acquire funding for all projects. This is the reason why it was crucial to prioritize projects to determine the most critical ones for Lima's environmental improvement. The financial team ranked projects according to three priority degrees: high, medium and low, and determined different sources of funding, both foreign and domestic. After one week to allow the completion of project proposals, the finance team had to evaluate budgets for each project and sector and compare them to Lima's budget for each sector in 2017 to determine if the domestic funding was within the $20 \%$ contribution of the city of Lima. However, during the process, the finance team did not interfere in the budget to be allocated to each sector or project with regard to foreign funding, as long as the foreign funding sources corresponded to the ones identified previously here, or justified by an innovative financial package. In the next part of this section, the details of each sector's project budget are presented, and the funding assessment is explained further.

\subsection{Project Assessment}

Data on each of the projects proposed from the different sectors were compiled into the grant application spreadsheet that was updated in real time, and which allowed the finance team to provide accurate and up-to-date feedback on project finance. The document detailed project costs and funding requests, as well as any identified aid, foreign direct investment or available municipal funds.

\subsubsection{Project Financing}

As each team began to finalize the projects that it wanted to propose for Lima, the finance team asked that they fill out the grant application spreadsheet. This 
document helped the teams to get a better understanding of what kind of financial considerations they needed to be making, and it also helped the finance team to understand better the various projects being proposed and how they might interact and affect one another.

For each proposed project, the teams were asked to identify the total cost of the project in US dollars (US\$) as opposed to the local currency, which is soles (S/.) and has an exchange rate of US\$ 0.31 . Teams were instructed to consider additional project costs beyond construction such as environmental studies, maintenance and labor costs. In order for the finance team to make accurate and fair assessments of each project's priority, the teams were asked to provide the project's area of impact, its perceived level of prioritization, as well as any comments they felt necessary to describe the importance of their project. The percentage of financing assumed to be covered by the city of Lima was determined after the projects were fully submitted in the Grant Application; teams were provided with a column to make note of any additional aid or investment they felt might be needed for the development of their project

\subsubsection{Proposed Government Financing}

As mentioned previously, Peru was one of the first countries in Latin America to make its Integrated Financial Management Information System (IFMIS) available to the public through its fiscal transparency portal, Portal de Transparencia Economica (Economic Transparency Portal). The finance team was able to access this information, use it to make informed estimates, and determine how much money could be allocated to each project.

Peru's total annual budget for 2017 was roughly US $\$ 47.5$ billion. However, with the availability of real time data, the finance team was able to observe that the country had already gone over budget with still a few months left to go in the fiscal year. Due to this, the finance team projected the data from the first three quarters of Peru's expenditures in 2017 to determine an estimated annual expense of $\$ 64.5$ billion. Knowing that Lima's annual budget for 2017 was set at $\$ 24.4$ billion, which is about $51 \%$ of the total annual budget for Peru, it was assumed that Lima would also go over its budget. After looking at the overall annual budgets, the finance team took a further look into how these dollars were allocated to the various divisions within the government structure of Peru. As each project proposal was reviewed, the finance team worked to find the most relevant division for each project and determine how much government funding could be hypothetically allocated to the project based on past expenditures and the current availability of funds. In addition to these financial considerations, it was necessary to consider as well any current or impending projects in and around the City of Lima that might have an effect on the feasibility of projects. It was assumed that $51 \%$ of each Peruvian government division's budget would be spent in Lima based on the total percentage makeup of the overall annual budget. 


\subsubsection{Proposed Domestic Aid and Investment}

Many of the proposed projects are funded, at least in part, by the Peruvian government. However, for some projects, the sources of funding are proposed to come from various non-governmental organizations (NGOs) or private enterprises that have a stake in the outcome of the project. In some cases, such as the grey water pipeline project, the sanitation team discovered that the state-owned water utility SEDAPAL was already working on implementing a large-scale infrastructure project. The energy team also discovered that Peru's largest energy provider Enel was already involved in implementing sustainable energy efforts in Peru and assumed that they would be able to invest in several projects including the solar array field, the biomass plan, and the electric bus fleet.

\subsubsection{Proposed International Funding}

For some projects, government financing and domestic partnerships are supplemented by international sources of funding. The agencies that have been selected as likely to fund the proposed projects include the World Bank, which is one of the most powerful and invested organizations for international project funding. It has been referenced as a source for helping to develop the microfinance NGOs/cooperative project and also some of the grey water pipeline project expenses. The Japan International Cooperation Agency (JICA) has also been included as an assumed source of funding for the grey water pipeline and for solid waste and education management due to its history of assisting with water supply and sewage. The Inter-American Development Bank (IDB), as the main multilateral lender in Peru, has also been referenced in financing the solid waste and education management project. The Deutsche Gesellschaft für Internationale Zusammenarbeit GmbH (GTZ) is a German international development cooperation agency that has been cited as a source for the grey water pipeline project. FINCA, an international non-profit microfinance organization, has been assumed to assist in funding the microfinance NGOs/cooperative project, along with the International Monetary Fund (IMF). A non-profit called Grand Challenges Canada has been selected as a possible funding source for the Waterwheel project due to its interest in funding solutions that impact community health. The Bank of China has been referenced as likely to help cover some of the costs for the solar array field project based on its history of financing technological developments in Peru. Enel, an Italian international manufacturer and distributor of energy, is the lead distributor in Peru and has been assumed to partner on the energy projects, specifically assisting with the skilled labor-training project, the biomass plant project, and the electric bus fleet project. Barefoot College, a social work and research center known for working in the field of education and skill development, has also been referred to as a partner for the implementation of the skilled labor-training project. Finally, one of the last agencies that is referenced in this document as a potential source for foreign aid is Water for People, an American nonprofit that improves water quality and access in developing countries, helping to facilitate the community water education project. 
Foreign Direct Investment (FDI) options were also considered when examining how to cover the costs of these proposed projects. As stated above, Peru has been experiencing a decline in FDI. However, it can be assumed that some large-scale companies are still interested in investing in Lima's diverse industry. Build Your Dreams Auto Company (BYD) has been identified as a company that would be likely to invest in Lima's automobile manufacturing industry and finance the development of the electric bus assembly plant project. Hewlett-Packard Company (HP), an American informational technology company, has been selected to facilitate the development of the electronics manufacturing project as well as the technical and vocational schools project. Finally, as the last source of proposed FDI, Kraft Heinz Inc. of the US has been referenced as a potential partner for the food processing plant project.

\subsection{Conclusion}

Financing public projects, through reinforcing local governance, is a first step towards abolishing social and economic gaps in the City of Lima. As was mentioned previously, FDI declined considerably, and, thus, the city had to develop innovative ways to finance investment projects, combining regional governments funds, local sources of funding, and foreign aid, including grants and subsidized loans. The finance team identified sources of local funding and foreign aid, emphasizing sectors funded by each institution or organization, the goal being to diversify sources of funds and make funding sources available for a 5 -year period. Lima's economy is growing, and it is partially due to several ongoing investment projects. Therefore, the financial team had to allocate funds to high priority, innovative projects, with regard to their scale and the impact assessment, for instance. As a result, the financial team established a grant application to be filled out by all sector teams, to summarize all project aspects to clarify the business plan. Teams have had to assume different levels for each source of funding, from the established database, without exceeding $20 \%$ allocated to domestic funding. Teams with a remaining balance had to seek other sources of funding other than the ones benchmarked, such as banks, foundations and NGOs. These investment projects seek to improve the Lima population's socio-economic situation, but also, to improve Lima's ranking among world capitals, as all the teams' projects can be included in the development agendas of which Lima is currently a part. Table 8 summarizes the total cost of the 5-year environmental plan for Lima, the percentage of the total budget by sector and the sources of funds.

\section{Concluding Remarks}

The intent of this project was to bring the contemporary thinking and practice of Urban Environmental Management to the solution of real problems in a major city in an important developing country of South America. The exercise, then, was to replicate as much as possible the conditions under which a team of 
Table 8. Project financing totals.

\begin{tabular}{cccc}
\hline Total Cost (USD) & $\begin{array}{c}\text { Financing from } \\
\text { City of Lima }\end{array}$ & $\begin{array}{c}\text { Domestic Aid or } \\
\text { Investment }\end{array}$ & $\begin{array}{c}\text { Foreign Aid or } \\
\text { Investment }\end{array}$ \\
\hline$\$ 1,099,025,000$ & $\$ 70,935,000$ & $\$ 115,600,000$ & $\$ 912,490,000$ \\
\hline
\end{tabular}

Source: Author.

expatriate consultants would operate in this context so that they could develop solutions that fit the circumstances they would likely find as professional planners working on such projects for international development banks (e.g., the World Bank or the Inter-American Development - IDB), multilateral donors in the United Nations system, such as the United Nations Development Program (UNDP), the Food and Agricultural Organization (FAO) or the Industrial Development Organization (UNIDO), as well as the numerous bilateral donors of the developed countries, which are primarily known by the alphabet soup of their initials (USAID, JICA, SIDA, CIDA, GTZ, NORAD, etc.). Major donor countries include the United States, Japan, Canada, Australia, United Kingdom, Germany, France, the Netherlands, Switzerland, Sweden, Denmark, Norway, Finland, Italy, Belgium and Spain. Consulting firms operating internationally on projects these institutions and countries fund come not only from the donor countries named, but increasingly from countries such as Brazil and India as well, and the staffs of experts they provide often come from a number of the countries named (Edelman, 2014).

Of course, a desk study conducted by students outside of Peru in a five-month period has its limitations. First, only data available on the internet are accessible, and there is no way to test accuracy. Fieldwork, including local observations of existing conditions, capabilities and prices, as well as interviews with government officials, academics, employees of service providers and non-governmental organizations and residents, could not be accomplished.

Nevertheless, in this working environment, it was an instructive academic exercise for the students to formulate a 5-year plan of solutions to the environmental problems and issues they faced rather than to be told how to solve them. This expanded their analytical skills and taught them how to utilize the limited knowledge and resources available to come up with implementable solutions for the benefit of the population of the Lima agglomeration. They learned that such skills are transferable to other projects, and they gained a greater appreciation of the skill set that they are developing as planners (Edelman 2016). Bringing the reality of development to the classroom and asking students to confront it gives them an appreciation of professional practice that the study of theory alone does not. It also exposes them to the social significance of their future professions. Thus, this project has attempted not only to expand the education of planning graduate students, but also to provide a meaningful contribution to planning pedagogy (Edelman, 2015). 


\section{References}

ABOD (n. d.). ABOD Shelters Solution.

http://www.abodshelters.com/solution/

ABOD Official Website (2017). ABOD Simple Design.

About Grand Challenges Canada (2017). Grand Challenges Canada. http://www.grandchallenges.ca/who-we-are/

ACCION International (2007). A Comparison of Housing Finance Programs for Low Income People in Peru. Peru Case Study for Cities Alliance.

https://www.microfinancegateway.org/sites/default/files/mfg-en-case-study-a-compari son-of-housing-finance-programs-for-low-income-people-in-peru-may-2007.pdf

Alcazar, L., Xu, C., \& Zuluaga, A. (2000). Institutions, Politics, and Contracts, the Attempts to Privatize Water and Sanitation Utility of Lima, Peru. World Bank. http://documents.worldbank.org/curated/en/907981468774890395/pdf/multi-page.pdf

Arana, M. (2013). Opinion: The Peru Kids Left Behind by the Boom. http://www.nytimes.com/2013/03/21/opinion/arana-the-kids-left-behind-by-the-boom . html

Barbier, C. (2012). Lima's Urgent Priority Is to Reform Public Transport. The Guardian. https://www.theguardian.com/world/2012/sep/11/lima-peru-public-transport-reform

Black, G. (2010). The Real Price of Water: The Future's Rare Resource. Karikuy. http://www.karikuy.org/blog/2010/12/12/the-real-price-of-water-the-futures-rare-reso urce/

Bonzangio, L., Kalra, N., Groves, D., \& Brandon (2015). Ensuring Robust Water Management Strategies in Lima-Callão, Peru. The Water Blog.

Cass Community Social Services (2017). Tiny Homes. https://casscommunity.org/tinyhomes/

Chauvin, L. (2009). Peru's Scavengers Turn Professional. http://content.time.com/time/world/article/0,8599,1878475,00.html

CINYDE (2011). Assessment of the Peruvian Market for Sustainable Energy Finance. http://www.ifc.org/wps/wcm/connect/78f59b00493a76e18cc0ac849537832d/SEF-Mark et+Assessment+Peru-Final+Report.pdf?MOD=AJPERES

Ciudad Saludable (2011). Ciudad Saludable: Video Institucional. https://www.youtube.com/watch?v=W4ZC-487M_c

Ciudad Saludable (2015). Colabora con los recicladores y recicladoras del Perú. https://www.youtube.com/watch?v=AasSZVLWgUQ

Collyns, D. (2015). Farmer Waters Crops with Hose. [Photograph] https://www.theguardian.com/global-development/2012/sep/19/peru-fog-catchers-wat er-supplies

Conrad, N. (2012). Peru Battles to Bring Water to a dry Capital. Deutsche Welle. http://www.dw.com/en/peru-battles-to-bring-water-to-a-dry-capital/a-16453103

Corporate Vattenfall (2016). The Biomass Plant and How it Works. https://corporate.vattenfall.com/about-energy/renewable-energy-sources/biomass/how -it-works/

Countries - Peru - Our Action. (n. d.).

https://www.caf.com/en/countries/peru/our-action/

Dazzle Prints (2017).

https://www.dazzleprinting.com/online-printing/booklet-printing/?gclid=CjwKCAjwss vPBRBBEiwAS- 
FoVd6y4dqjeV7sh0FjRdC8HhkLbFmYP3-B6xvVQRSip5ZjJ1dmgCIVpLhoC4LcQAvD B BwE

Distribution in Peru (2015).

https://www.enelamericas.com/en/aboutus/a201609-distribution-in-peru.html

Edelman, D. J. (2014). Managing the Urban Environment - Mysore, India. Saarbrücken: LAP LAMBERT Academic Publishing.

Edelman, D. J. (2015). Managing the Urban Environment - Lagos, Nigeria. Saarbrücken: LAP LAMBERT Academic Publishing.

Edelman, D. J. (2016). Managing the Urban Environment - Manila, the Philippines. Saarbrücken: LAP LAMBERT Academic Publishing.

Edelman, D. J., Schuster, M., \& Said, J. (2017). Urban Environmental Management in Latin America, 1970-2017. Current Urban Studies, 5, 305-331.

https://doi.org/10.4236/cus.2017.53017

El Espectador (2017). El futuro de los recicladores en Bogotá. El Espectador. https://www.elespectador.com/noticias/bogota/el-futuro-de-los-recicladores-en-bogota -articulo-682513

Emery, A. (2017). Peru to Build 1290 Water Projects in 2017. BN Americas. http://www.bnamericas.com/en/news/waterandwaste/peru-to-build-1290-water-projec ts-in-2017

Enel Starts Construction of Peru's Largest Solar PV Plant (2017). Enelgreenpower.com. https://www.enelgreenpower.com/media/press/d/2016/11/enel-starts-construction-ofperus-largest-solar-pv-plant-

Export.gov (2017). Leading Sectors for U.S. Export \& Investment. Peru - Water Resources. https://www.export.gov/article?id=Peru-Water-Resources

Fernández, R. (2000). Gestión ambiental de ciudades: Teoría crítica y aportes metológicos. México: Programa de las Naciones Unides para el Medio Ambiente.

Fernández-Maldonado, A. M., \& Bredenoord, J. (2010). Progressive Housing Approaches in the Current Peruvian Policies. Habitat International, 34, 342-350.

https://doi.org/10.1016/j.habitatint.2009.11.018

Food and Agricultural Organization of the United Nations (2015). Urban and Peri-urban Agriculture in Latin America and the Caribbean: Lima.

http://www.fao.org/ag/agp/greenercities/en/ggclac/lima.html

Foreign Direct Investment (n. d.).

http://www.investinperu.pe/modulos/JER/PlantillaStandard.aspx?are $=1 \& p r f=0 \& j e r=60$ $37 \& \sec =17$

Fretes-Cibils, V., Giugale, M., \& Newman, J. L. (2007). An Opportunity for a Different Peru: Prosperous, Equitable, and Governable. Washington DC: World Bank. https://doi.org/10.1596/978-0-8213-6862-6

Graf, J., \& Kayser, O. (2014). Designing the Next Generation of Sanitation Business (pp. 80-84). HYSTRA Hybrid Strategy Consulting. http://www.toiletboard.org/media/10-27-Designing.pdf

IDB (2012). Housing Deficit in Latin America and Caribbean. http://www.iadb.org/en/news/news-releases/2012-05-14/housing-deficit-in-latin-ameri ca-and-caribbean, $9978 . \mathrm{html}$

Important Facts and Figures about Lima, the Capital of the Republic of Peru. http://www.limaeasy.com/lima-info/important-facts-and-figures-about-lima

Intelligence Series: The Perils of Plenty in Peru's Electricity Sector (2017). Bnamericas.com. 
https://www.bnamericas.com/en/intelligence-series/electricpower/the-perils-of-plentyin-perus-electricity-sector/

Jewell, N. (2014). Revolutionary Water Wheel Helps Women Transport Water More Efficiently in India. Inhabitat.

https://inhabitat.com/revolutionary-waterwheel-helps-women-transport-water-more-e fficiently-in-india/

Kalra, N., Groves, D., Bonzanigo, L., Molina Perez, E., Ramos, C., Brandon, C., \& Rodriguez Cabanillas, I. (2015). Republic of Peru Robust Decision-Making in the Water Sector a Strategy for Implementing Lima's Long-Term Water Resources Master Plan. The World Bank, 9.

http://documents.worldbank.org/curated/en/907711468144901879/pdf/AUS3381-REVI SED-PUBLIC-SEDAPAL-Report-2015-10-06.pdf https://doi.org/10.1596/1813-9450-7439

Lavars, N. (2014). Waterwheel Aims to Lighten the Load For Women in Developing Nations. New Atlas. https://newatlas.com/wello-waterwheel-water-transport/30325/

Lima Traffic Pattern, 2017.

Lineback, N., \& Gritzner, M. L. (2010). Peru’s Water Running Out. https://www.birdvilleschools.net/cms/lib/TX01000797/Centricity/Domain/3064/Peru\% 20Water\%20Running\%20Out.pdf

Livezey, E. T. (1980). “Hazardous Waste”. Christian Science Monitor. https://www.csmonitor.com/1980/1106/110653.html

Mahapatra, S., \& Mahapatra, S. (2017). Enel Commissions Largest Solar Project in South America/CleanTechnica.

https://cleantechnica.com/2017/09/25/enel-commissions-largest-solar-project-south-a merica/

McDonough, W., \& Braungart, M. (2002). Cradle to Cradle: Remaking the Way We Make Things. New York: North Point Press.

McGrath, M. (2014). Man Riding Back of Water Truck. [Photograph]

http://www.bbc.com/news/science-environment-30390041

Mervin, J. (2015). In Peru Water is a High Price for Lima's Poor. BBC News. http://www.bbc.com/news/business-34451418

Ministerio de Energía y Minas República del Perú (MEM Perú) (2017). https://www.bnamericas.com/company-profile/en/ministerio-de-energia-y-minas-repu blica-del-peru-mem-peru

Miranda, S., Calderón, L. J., \& Díaz Palacios, J. (1996). La situación de la gestión urbana ambiental en el Péru. In L. Miranda Sara, (Ed.). Ciudades para la Vida: Experiences exitoses y propuestas para la acción, PGU Serie Gestión Urbana No. 6. Lima: United Nations.

Miriam Vale Shire Council (2007). Engineering Estimates and Financial Implication of Pipeline and Desalination Options for Agnes Water and 1770.

http://www.gladstone.qld.gov.au/c/document_library/get_file?uuid=6a16fd7e-9c70-4b7 3-9cb6-8360dfa5e123\&groupId $=1570002$

Municipalidad Metropolitana de Lima (2013). Solid Waste Management in the City of Lima Peru.

http://www.waste.ccacoalition.org/sites/default/files/files/events_documents/RESIDUO S\%20LIMA\%20-\%20ENGLISH.pdf 
National Environmental Policy Act (1969). National Environmental Policy Act. https://www.whitehouse.gov/sites/whitehouse.gov/files/ceq/NEPA_full_text.pdf

Organismo de Evaluación y Fiscalización Ambiental (2014) Environmental Enforcement in Solid Waste. https://www.oefa.gob.pe/?wpfb_dl=11827

Ortegon-Sanchez, A., \& Hernandez, D. O. (2016). Assessment of the Potential for Modal Shift to Non-Motorised Transport in a Developing Context: Case of Lima, Peru. Research in Transportation Economics, 60, 3-13. https://doi.org/10.1016/j.retrec.2016.05.010

Pacala, S., \& Socolow, R. (2004). Stabilization Wedges: Solving the Climate Problem for the Next 50 Years with Current Technologies. Science, 305, 968-972. https://doi.org/10.1126/science.1100103

Painter, J. (2007). Peru's Alarming Water Truth. BBC. http://news.bbc.co.uk/2/hi/americas/6412351.stm

Peru and the IDB (n. d.). http://www.iadb.org/en/countries/peru/peru-and-the-idb,1037.html

Peru Economy - GDP, Inflation, CPI and Interest Rate (2017). https://www.focus-economics.com/countries/peru

Peru Total Gross External Debt Forecast (n. d.). https://tradingeconomics.com/peru/external-debt/forecast

Peru: Farming Sector Sees Best Growth in 2 Years (2017). http://www.andina.com.pe/Ingles/noticia-peru-farming-sector-sees-best-growth-in-2-y ears-678986.aspx

Peru's Energy Future (2017). International Rivers. https://www.internationalrivers.org/blogs/233/peru-s-energy-future

Peru's Fishing Industry likely to Expand 40\% This Year (2017). http://www.andina.com.pe/ingles/noticia-perus-fishing-industry-likely-to-expand-40-t his-year-654275.aspx

Peru's Stance on Paris Agreement and Climate Change|Noticias|Agencia Andina (2017). Andina.com.pe. http://www.andina.com.pe/ingles/noticia-perus-stance-on-paris-agreement-and-climat e-change-669391.aspx

Poon, L. (2016). The Garbage Fighting Vultures of Peru. The Atlantic. https://www.theatlantic.com/international/archive/2016/01/peru-vultures-garbage/431 $\underline{709 /}$

Quistberg, D. A., Koepsell, T. D., Johnston, B. D., Boyle, L. N., Miranda, J. J., \& Ebel, B. E. (2015). Bus Stops and Pedestrian-Motor Vehicle Collisions in Lima, Peru: A Matched Case-Control Study. Injury Prevention, 21, E15-E22. https://doi.org/10.1136/injuryprev-2013-041023

Radelet, S. (2006). A Primer on Foreign Aid. https://www.cgdev.org/

Robinson, D. J. (2016). Lima. https://www.britannica.com/place/Lima

Roman, A., Winker, M., Tettenborn, F., \& Otterpohl, R. (2007). Informal Settlements and Wastewater Reuse: Improve of Urban Environment and Alleviate Poverty in Lima, Peru. https://www.researchgate.net/publication/228613769_Informal_Settlements_and_Wast ewater_Reuse_Improve_of_Urban_Environment_and_Alleviate_Poverty_in_Lima_Peru

Schneider, K. (2014). Growth in Lima, Peru's Capital, Served without Water. Circle of 
Blue.

http://www.circleofblue.org/2014/world/growth-lima-perus-capital-served-without-wa ter/?utm_source=rss\&utm_medium $=$ rss\&utm_campaign=growth-lima-perus-capital-s erved-without-water

Seguimiento de la Ejecución Presupuestal (Consulta Amigable) (n. d.). https://www.mef.gob.pe/es/?option=com_content\&view=article\&id=504\&Itemid=1009 $\underline{44}$

Skinner, L. (2017). Personal Communication. E-mail.

Staff, I. (2015). Foreign Direct Investment - FDI. https://www.investopedia.com/terms/f/fdi.asp

Tedagua (2014). Taboada WWTP (Lima, Peru) South America's Largest Wastewater Treatment Plant.

Tejerina, Alfonso (2015). Power in Peru.

http://www.powermag.com/wp-content/uploads/2015/02/Peru-Power_2014_v6-web-R ES.pdf

The Many Benefits of Drip Irrigation (2017). https://www.dripdepot.com/article/benefits-of-drip-irrigation

The World Bank (1991). Lima Water Supply and Sewerage Project-Project Completion Report.

The World Bank Group's Peru Portfolio and Climate Change (2015). http://www.bing.com/cr?IG=38EF0A0EEF7D466B8B5C4DAB7FFBE064\&CID=2F6B2 59E8BD8657930F52ECF8A776411\&rd=1\&h=YUfQ2-5VrZ27DVxXoudeABhQezVKIX qtTJmJHnXJYX$\mathrm{o} \& \mathrm{v}=1 \& \mathrm{r}=\mathrm{http} \% 3 \mathrm{a} \% 2 \mathrm{f} \% 2 \mathrm{fwww}$.bankinformationcenter.org\%2fwp-content $\% 2$ fuploads \%2f2015\%2f08\%2fPeru-Climate-Change-full.pdf\&p=DevEx,5068.1

The World Bank in Peru (2017). http://www.worldbank.org/en/country/peru

Trading Economics (Database) (2017). https://tradingeconomics.com/

UN Habitat (2005). Financing Urban Shelter: Global Report on Human Settlements 2005. London: Earthscan and UN Habitat.

UN Habitat (2008). The Human Settlements Finance Systems Series. In X. Q. Zhang, (Ed.), Housing Finance Mechanism in Peru. Translated by Osanjo. Nairobi, Kenya: United Nations Human Settlement Programme.

United Nations (2014). In Peru, Where Evidence of Climate Change Is Abundant, Hope for a Solution Is, Too - UN and Climate Change.

http://www.un.org/climatechange/blog/2014/11/peru-evidence-climate-change-abunda nt-hope-solution/

Urban Conceptual Authority 129, accessed 21 October 2017.

Wello Water Wheel (2017). https://Wellowater.org/

WHO (World Health Organization) (2013). Lima's Trash and Health Link. http://www.who.int/en/

World Atlas: Lima Population (2013). Knoema. https://knoema.com/atlas/Peru/Lima/topics/Demography/Age-Structure/Population-0 -14-Years

World Bank (2007). Análisis Ambiental del Perú, Retos para un Desarrollo Sostenible. http://siteresources.worldbank.org/INTPERUINSPANISH/Resources/Res_Ejec_CEA_ FINAL.pdf

World Justice Project (2017). Promoting Access to Sustainable Transport in Lima 
Through the Use of Bicycles as Means of Transport.

https://worldjusticeproject.org/our-work/programs/promoting-access-sustainable-tran sport-lima-through-use-bicycles-means-transport

Yachiyo Engineering (2005). The Master Plan for Lima and Callao Metropolitan Area Urban Transportation in the Republic of Peru (Phase 1). Volume 1, accessed 17 November 2017. 